\title{
21. MINERALOGY, PETROGRAPHY, DISTRIBUTION, AND ORIGIN OF THE MESSINIAN MEDITERRANEAN EVAPORITES
}

\author{
W. D. Nesteroff, University of Paris VI, France
}

\section{INTRODUCTION}

Jacques Bourcart was the first to draw attention, in the middle of the nineteen fifties, to the knolls of the Ligurian Abyssal Plain which are the superficial topographic expression of the piercement structures of the Mediterranean evaporites (Bourcart et al., 1958, Bourcart 1959). Later, Alinat and Cousteau (1962), followed by Hersey (1965) interpreted them as salt diapirs, followed by Glangeaud $e t$ al. (1966). Since that time, various solutions were proposed regarding the petrographic nature and the age of the Mediterranean deep-sea diapirs (Mauffret 1969, Watson and Johnson 1968, etc.).

The problem of the peri-Mediterranean evaporites is not a simple one. Important salt deposits of Triassic age are known throughout the western Alps. In addition, elevated shreds of evaporitic series of Messinian age are observed around the different Mediterranean basins. In this context, the relationship of the deep sea diapirs to the geological outcrops of evaporites of different ages was not obvious. The scientific shipboard party of Leg 13 was well aware of this situation and consider confirmation of the evaporitic nature of the deep-sea diapirs and the discovery of their Messinian age a major step to an understanding of the Cenozoic geological history of the western Alps. Our drilling proved the existence of a huge geological formation of Messinian Mediterranean evaporites well defined by its lithology and time boundaries (Figure 1). All of the shreds of Messinian evaporites scattered around the Mediterranean, and the deep-sea diapirs, belong to this formation, which is younger in age than, and distinct from, the Triassic evaporites of the same region.

Since discovery of the deep-sea diapirs and the corroboration of their salt nature (Ewing, Worzel, et al., 1969), the problem of the depositional mechanism of the salts, now underlying several thousand meters of water, has never ceased to attract attention. Traditionally, authors considered that the evaporites precipitated under a very thin layer of water. Recently however, Schmalz (1969) proposed several models of precipitation in deep water that could account for deep deposits such as those which have been discovered in the Gulf of Mexico.

In this context, the interpretation of Leg 13 findings becomes all the more important because none of the existing theories account completely for our results. Thus we felt the need for a new explanation. In this chapter, we present the petrographic and mineralogic results together with all the pertinent data which may help to solve this problem. These different results are organized into a coherent group of observations which, however, may be interpreted in two different ways. In the discussion, we show how these observations have led us to the choice of a shallow-water, shallow-basin desiccation model for the Messinian Mediterranean evaporites.

\section{STRATIGRAPHY}

\section{Valencia Gulf (Site 122)}

Site 122 is located in one of the canyons of the complex channel system of the Valencia Gulf. Drilling first penetrated the turbidite and contourite filling of the channel. At 156 meters, hard stringers were encountered and the hole bottomed at 162 meters in a hard horizon. No cores were recovered from this interval, but after the withdrawal of the drill string, we discovered the bottom assembly plugged by gravel, while marls with gypsum were wedged between the teeth of the drill bit (see Chapter 4).

\section{Gravel}

The gravel, ranging in size from 2 to $20 \mathrm{~mm}$, is mixed with sand of the same composition and in the ratio $60 / 40$ per cent. It also contains a small amount of clay-size material which was probably absent in the original bed and may have resulted from mixing during drilling. The gravel is composed of 70 per cent basalt fragments, some of which are rounded; 25 per cent gypsum crystals; and 5 per cent fragments of pelagic limestone. Also present are a mixture of shallow- and deep-water foraminifera of PlioceneMiocene age, shallow-water shell debris, algal biscuits, and fragments of chert and andesite. The gypsum occurs as large as 1 to $5 \mathrm{~mm}$ crystals with fresh lustre. Cleavage and fracture planes suggest that the fragments belonged originally to large crystals such as those embedded in lagoonal marls. A good example of this facies is found at Site 124, Core 7.

\section{Evaporitic Suite}

The sediment recovered from the drill bit is a medium gray marl with large nodules of white saccharoidal gypsum. The marl is comprised of quartz, calcite, feldspar, and trace amounts of dolomite. The nannoplankton fauna belongs to the lower upper Pliocene, with reworked species (see Chapter 4).

\section{Discussion of Site 122}

The hard horizon in which the hole bottomed is probably a layer of massive gypsum interbedded with marls and loaded with saccharoidal gypsum. Lumps of this marl were recovered on the drill bit.

One possible conclusion is that these marls are the equivalent of terminal marls of the Messinian evaporitic suite cored in some other sites, such as 124,134 , and 132 . In this case, the lower Pliocene fauna would result from contamination during drilling. Alternatively the evaporitic conditions in the marginal Gulf of Valencia continued after 
VALENCIA CHANNEL

122

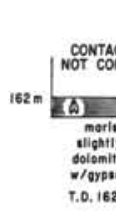

BALEARIC RISE

124

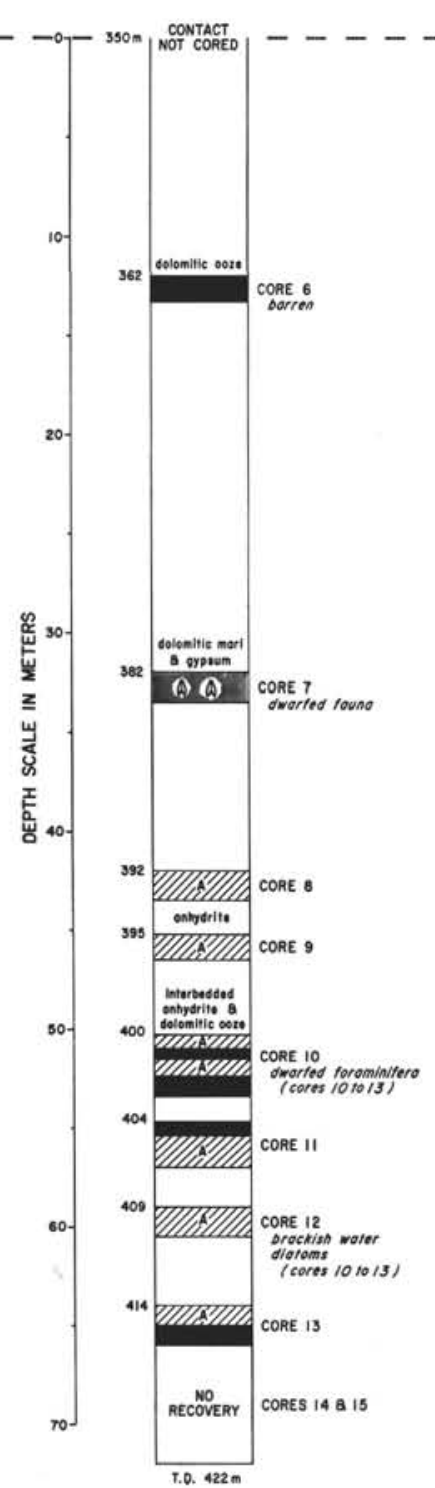

BALEARIC ABYSSAL PLAIN

$$
134
$$

TYRRHENIAN BASIN

132
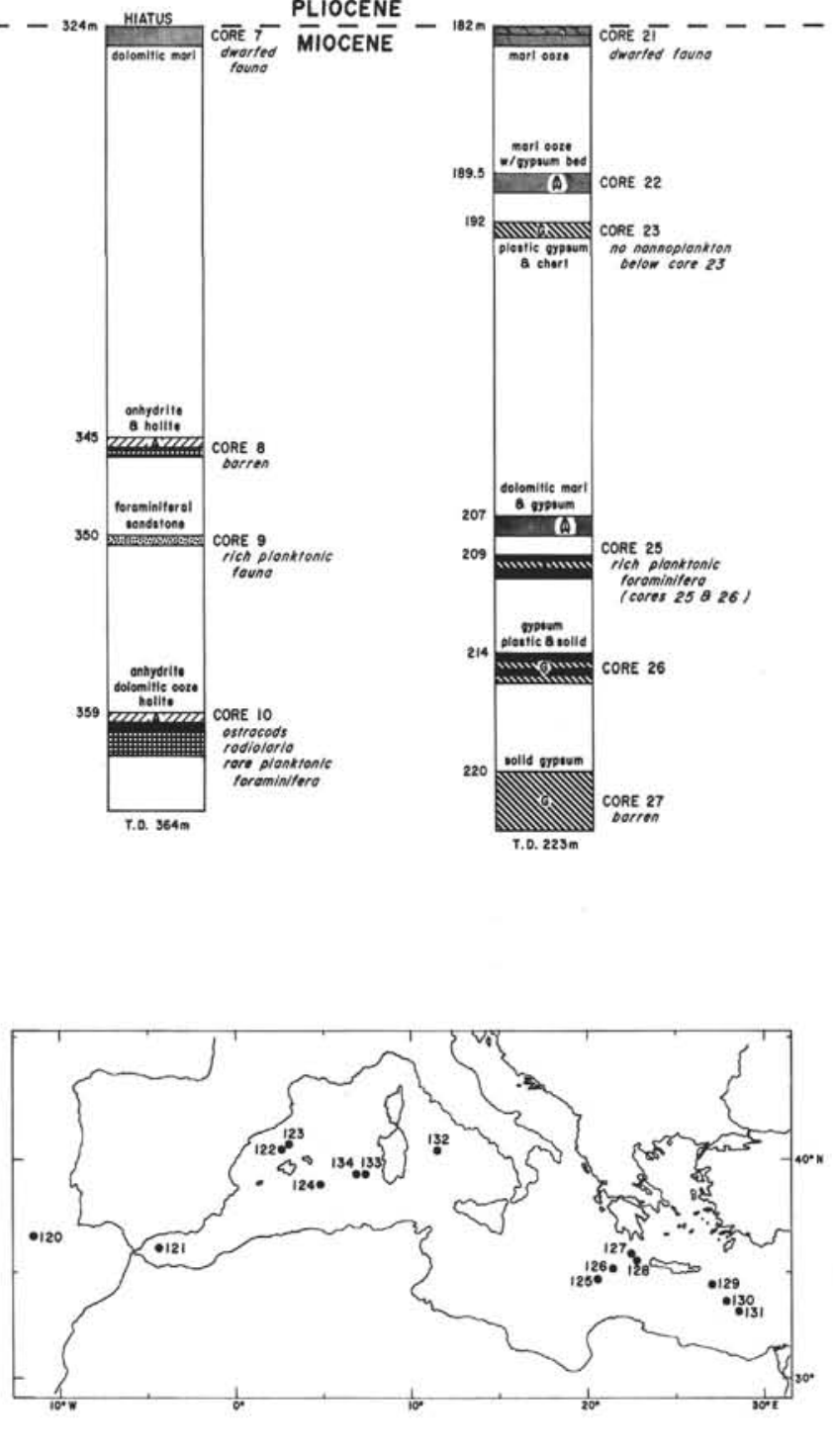

MEDITERRANEAN RIDGE
IONIAN BASIN

125

126
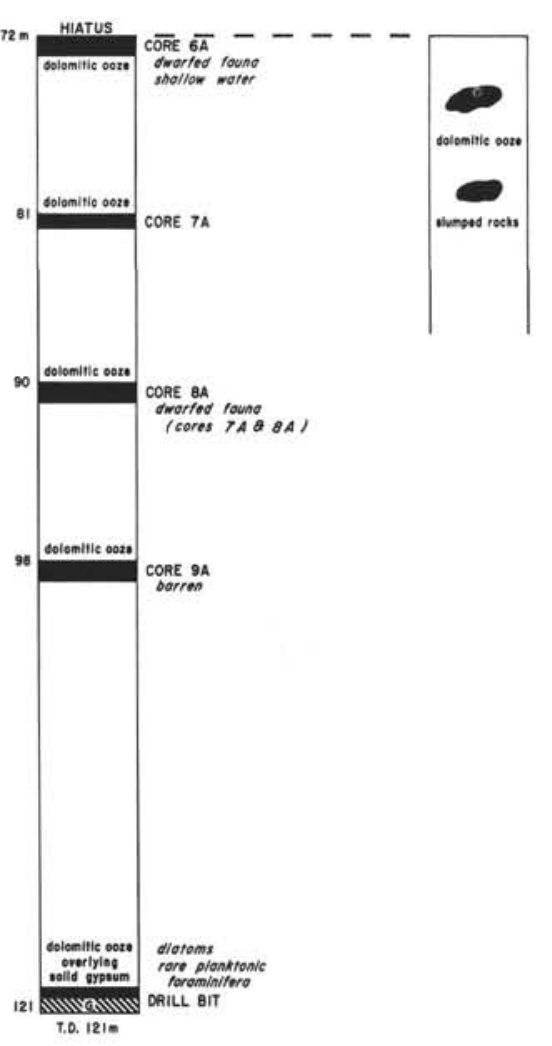

dolomitic marl (dolomite a coleite) dolomitic ooze (no calcite) forominiferal sondstone sypsum onhydrite halite

Figure 1. The evaporitic Messinian series drilled during Leg 13. 
the flooding of the central basins. Later, during the Pliocene, open marine conditions were restored, with the general subsidence of the western basin and the readjustments of its margins (see Chapter 45 ).

Seismic profiles show the continuity between the evaporitic formation of the central western basin and its digitation in the Valencia Gulf (Mauffret 1969, Montadert et al., 1970, and Chapter 48.2). However, only the upper part of the formation is present at Site 122. This is compatible with both hypotheses.

Interpretation of the gravel is also difficult. Two models may be proposed, based on the composition of the original gravel. If the material plugging the bottom assembly is identical to the gravel bed, this bed would be made up exclusively of upper Miocene and older components: basement basalts, Langhian-Tortonian limestones, and Messinian gypsum. It could represent the erosional products from the bottom of the Gulf of Valencia during the upper Miocene, i.e., a coarse horizon ending the evaporitic series. This sort of horizon is known to occur locally in the Italian Messinian evaporites (Ogniben, 1957). Pliocene deep-water benthonic formanifera would then be downhole contaminants from overlying nanno oozes.

On the other hand, if the original gravel bed contained no gypsum, the material in the bottom assembly would result from mixing during the drilling of two different horizons. The upper horizon consisted of basalt limestone gravel eroded, as in the first case, from the sea floor, but filling a Pliocene channel. The lower included marls with beds of solid gypsum. The second alternative allows the lower bed to be either Miocene or lower Pliocene in age.

\section{The Balearic Rise (Site 124)}

Site 124 is located at the foot of the Balearic Rise, near the abyssal plain. Drilling penetrated 359 meters of Quaternary and Pliocene turbidites and contourites before the evaporitic series was reached. The latter was drilled down to 422 meters. However, no sediments were recovered below 418 meters in Cores 14 and 15 .

The lower half of the evaporitic series consists dominantly of benches of massive anhydrite interbedded with dolomitic oozes, while only dolomitic oozes and marls were recovered from the upper half.

\section{The Anhydrites}

At the base of the hole, the dominant rock is massive anhydrite interbedded with dolomitic oozes. Individual anhydrite beds were 1 to 1.7 meters thick, but may originally have been thicker as recovery was poor here. A well-defined trend towards a poorer crystallization is noted in the anhydrite layers, not only from the bottom of the hole upward, but also within each individual bed of anhydrite.

A good example of the advanced replacement in the lower horizons is the large bed of Core 11 (Section 1, 130 $\mathrm{cm}$ to Section 2, $112 \mathrm{~cm}$ ). Below the contact with the overlying dolomitic ooze, the anhydrite is poorly recrystallized (Figure 2). The rock consists of a greenish gray matrix which still displays a faint bedding, making it fissile. Scattered large white nodules (5 to $10 \mathrm{~mm}$ ) grow at random along the bedding planes. Some centimeters below, a gradational transition to the mosaic facies is noted. The number of nodules increases. They grow and finally coalesce. Thin millimetric lines of greenish color separate

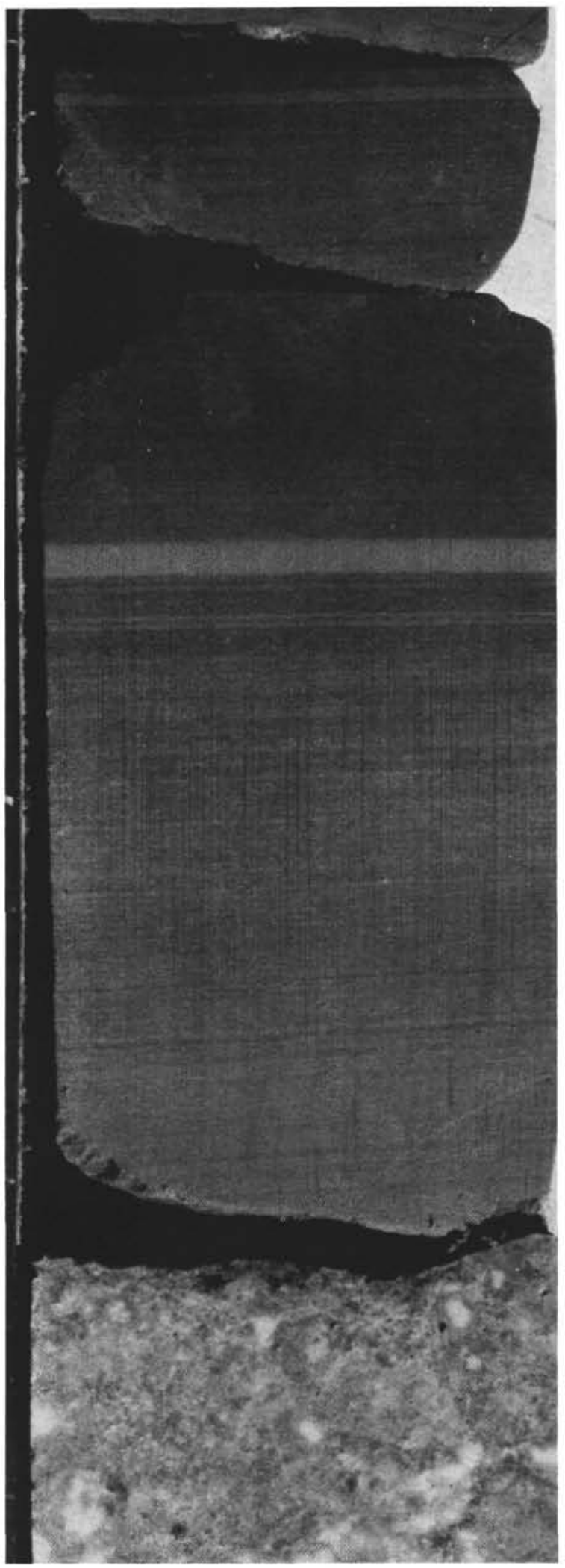

Figure 2. "Chicken-wire" texture in massive anhydrite. The white noduies are coalescent separated by fine lines of greenish color (124-13-3, 0 to $56 \mathrm{~cm}$, on scale). 
the individual nodules. The general appearance is that of a chicken-wire texture (Figure 3), also called mosaic or penemosaic texture (Rooney and French, 1968). Petrographic observations show that the nodules are of microsize, cryptocrystalline anhydrite (see Friedman, Chapter 22). The bulk of the bed consists of this mosaic texture. At the base of the bed, in the last $5 \mathrm{~cm}$, the undifferentiated greenish matrix reappears. X-ray analysis shows anhydrite, with trace amounts of gypsum, throughout the bed.

The mosaic texture, with transitional zones, characterizes Cores 13,12, and 11. A new texture is noted higher in the sedimentary column, in Core 10. A single bed of anhydrite (Core 10-2, 0-90 cm) consists of massive homogeneous rock. It is devoid of any particular structure. The general color is greenish, with rusty white patches and green streaks. This texture suggests a more advanced stage of recrystallization in which even the green lines of the mosaic have disappeared, the green streaks being the remnants of these lines.

In the same Core 10, at the base of Section 1, a gradation from massive to laminated anhydrite occurs. The laminae, 1 to $3 \mathrm{~mm}$ thick, are alternately white and green (see Friedman, Chapter 22).

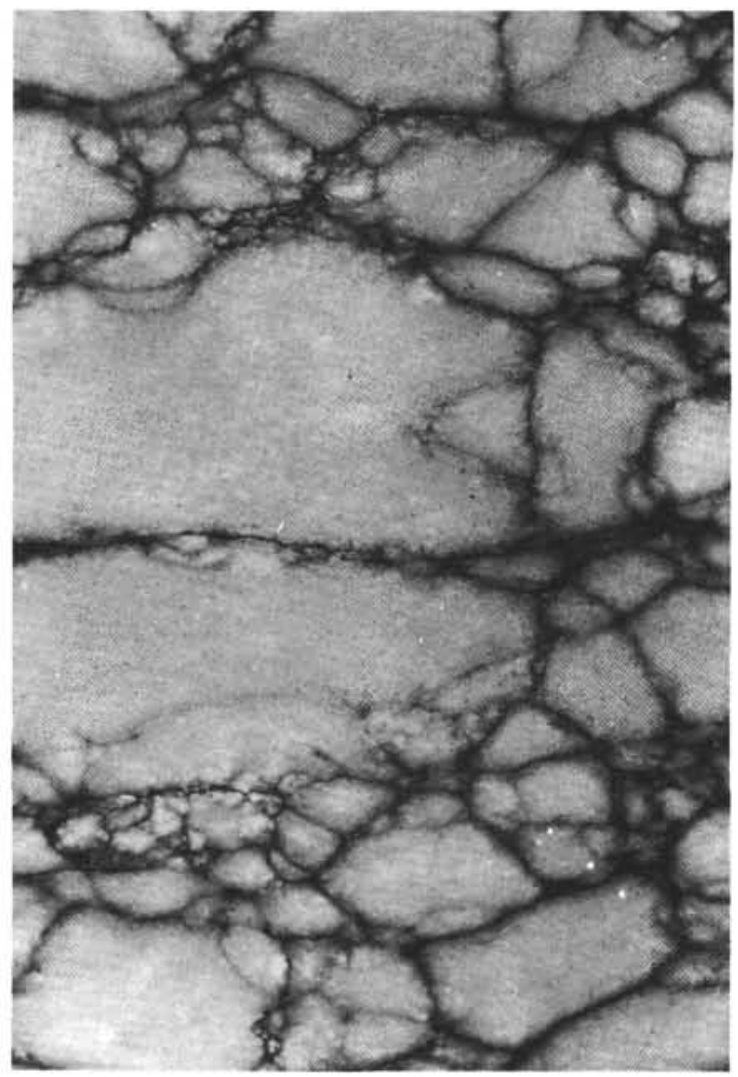

Figure 3. Dolomitic ooze overlying massive anhydrite. Note, in the dolomitic ooze the dark-and light-colored laminations. This ooze is still plastic and almost barren (see examples of SEM observations in Figures 4 and 5). The top of the massive anhydrite layer displays a greenish gray matrix with scattered white nodules (124-11-1, 115 to $110 \mathrm{~cm}$, on scale).
Overlying Core 9 contains a series of transitional facies. The top $(20-50 \mathrm{~cm})$ is a finely laminated rock. At $40 \mathrm{~cm}$, isolated white nodules appear along the stratification planes, obviously displacing the bedding. Their number and size increase downward. At $55 \mathrm{~cm}$, they reach a length of 5 $\mathrm{cm}$. Below this level, the texture is truly nodular, with large white nodules evenly distributed along bedding planes. A new facies change occurs below $110 \mathrm{~cm}$. The rock is again finely laminated, displaying alternate white and gray laminae, 1 to $10 \mathrm{~cm}$ thick. However, the original bedding only partially survives, often being obliterated or displaced by large white nodules. Finally, below $137 \mathrm{~cm}$, all structures disappear and the texture becomes macroscopically homogeneous as in Core 10 .

Core 8 contains the last uphole occurence of anhydrite. It also shows a very poor crystallization pattern. As in Core 9 , the rock is laminated but here it is fissile and breaks easily along the stratification planes. It consists of 2 to 3 mm thick beds of whitish gray anhydrite. The limits of the beds are outlined in black, probably by concentration of organic matter. Small white crystals of anhydrite occur in the majority of these beds. They are always aligned along stratifications and, when their size reaches 1 to $2 \mathrm{~cm}$, they displace the overlying bed (Figure 4).

Examination of smear slides of scrapings from the schistosity planes reveals fair amounts of calcareous nannoplankton, together with anhydrite crystals.

The bedding in Core 8 is generally horizontal. However, $20 \mathrm{~cm}$ of undulated laminae occur in the middle of the core, suggesting that a more advanced crystallization is responsible for this texture. At the base of the core, some large nodules mark the transition to the textures seen in Core 9.

\section{Interbedded Dolomitic Oozes}

Dolomitic plastic oozes are interlayered with the beds of massive anhydrite in the lower half of the series. They are generally 0.5 to 1 meter thick, but a thin isolated layer of $10 \mathrm{~cm}$ was noted. They are dark-colored (gray to dark olive gray) and contrast with the whitish color of the anhydrites. They are laminated. Thin dark gray to black layers $(1-2 \mathrm{~cm})$ with sharp boundaries alternate with lightly colored layers (Figure 3). They are still plastic in Core 10 at 400 meters, but become indurated in Core 11, below 404 meters.

$\mathrm{X}$-ray analyses show that the oozes are composed of dolomite, quartz, clays, and halite. The carbonate content is 40 to 60 per cent. X-ray analyses show an absence of calcite and indicate that, in the clay minerals, illite is dominant together with mixed layer clays and moderate amounts of montmorillonite and chlorite.

Under the microscope, the dolomite is seen as "oolite-type" crystals, less than $30 \mu$ in size. Scanning electron microscope (SEM) observations show that it consists of very small rombohedral crystals, 2 to $3 \mu$ in size (Figure 5). The small size of these crystals is noteworthy.

The dolomitic oozes are barren except for rare foraminifera and siliceous organisms. A few dwarfed specifens of Globigerina were observed in Cores 10 to 13 . Siliceous fossils, mainly diatoms, raiolarians, and sponge spicules, occur at specific horizons below 400 meters. At the bottom of the hole, in the last cored horizon (Core 13), extremely finely laminated layers, showing an alternation 

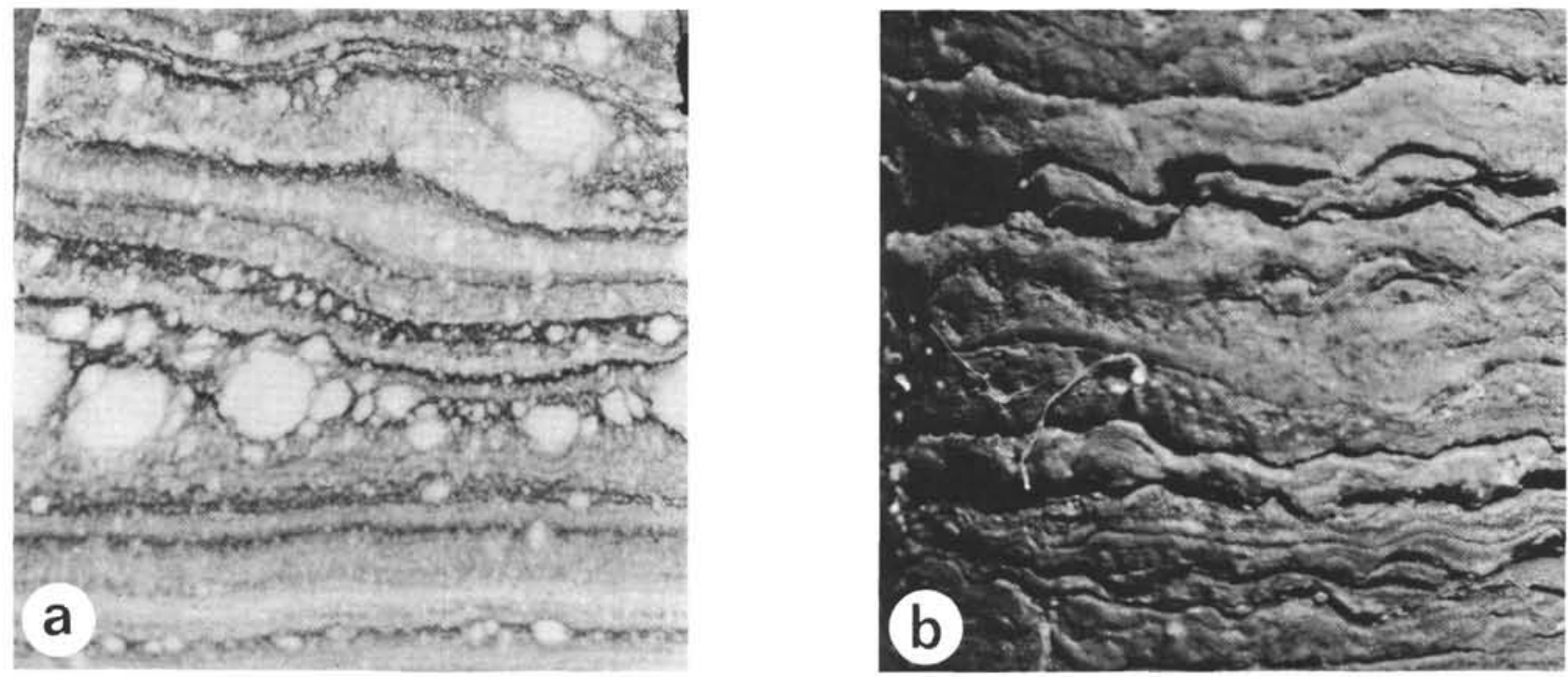

Figure 4. Dolomitic ooze interbedded between massive layers of anhydrite. Ultrastructure: $a \times 2350, b \times 12,000$. This ooze, still plastic, comprises dolomite together with quartz, feldspar, clays, and halite. Note the small size (2 microns) of the dolomite crystals, suggesting penecontemporaneous dolomite (124-10-1, $113 \mathrm{~cm})$.
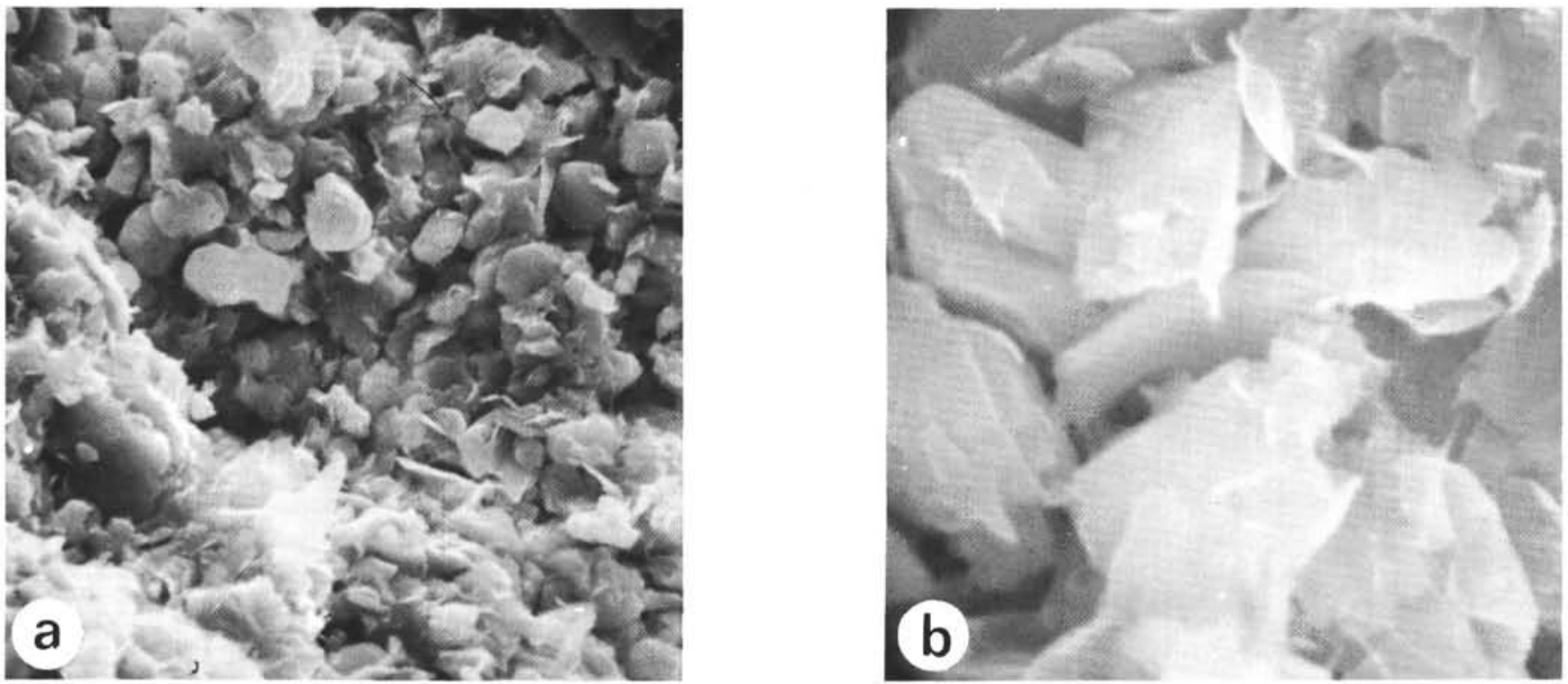

Figure 5. Dolomitic ooze interbedded between layers of massive anhydrite. This ooze, semi-indurated, comprises dolomite, quartz, clays, and halite. Ultrastructure: $a \times 2200, b \times 5500, c \times 5500, d \times 2200$. Figures a and c display pennate diatoms characteristic of brackish or marine waters. Note on Figures $b$ and $c$ the solution holes in the cubic crystals (124-13-2, $81 \mathrm{~cm}$ ).

of green and black laminae, were noted. They contain pennate diatoms together with siliceous sponge spicules (Figure 6). The last bed cored, at 418 meters, also displays volcanic glass shards.

\section{Terminal Dolomitic Marls}

The top of the evaporitic formation is composed of 35 meters of dolomitic marls and dolomitic oozes. There are no more thick layers of massive anhydrite. However, the disappearance of the sulfates is gradational; Core 7 displays many thin layers of gypsum, while Core 6 is free of salts.
Core $7(382-385 \mathrm{~m})$ is a dolomitic marl with gypsum. The sediment is finely bedded, plastic to stiff, and mainly light olive gray in color. It contains dolomite, calcite, quartz, clays, and pyrite, together with a poor dwarfed foraminiferal fauna (planktonic and benthic) and more abundant nannoplankton, the complete assemblage indicating open-sea conditions. Microscopic observations show that, in Core 7, calcite corresponds to nannoplankton and foraminifera, while the dolomite is present as "oolite-type" crystals. The clay minerals are illite, mixed-layer clays, and chlorite. Of note are numerous indurated layers, 0.1 to 5 

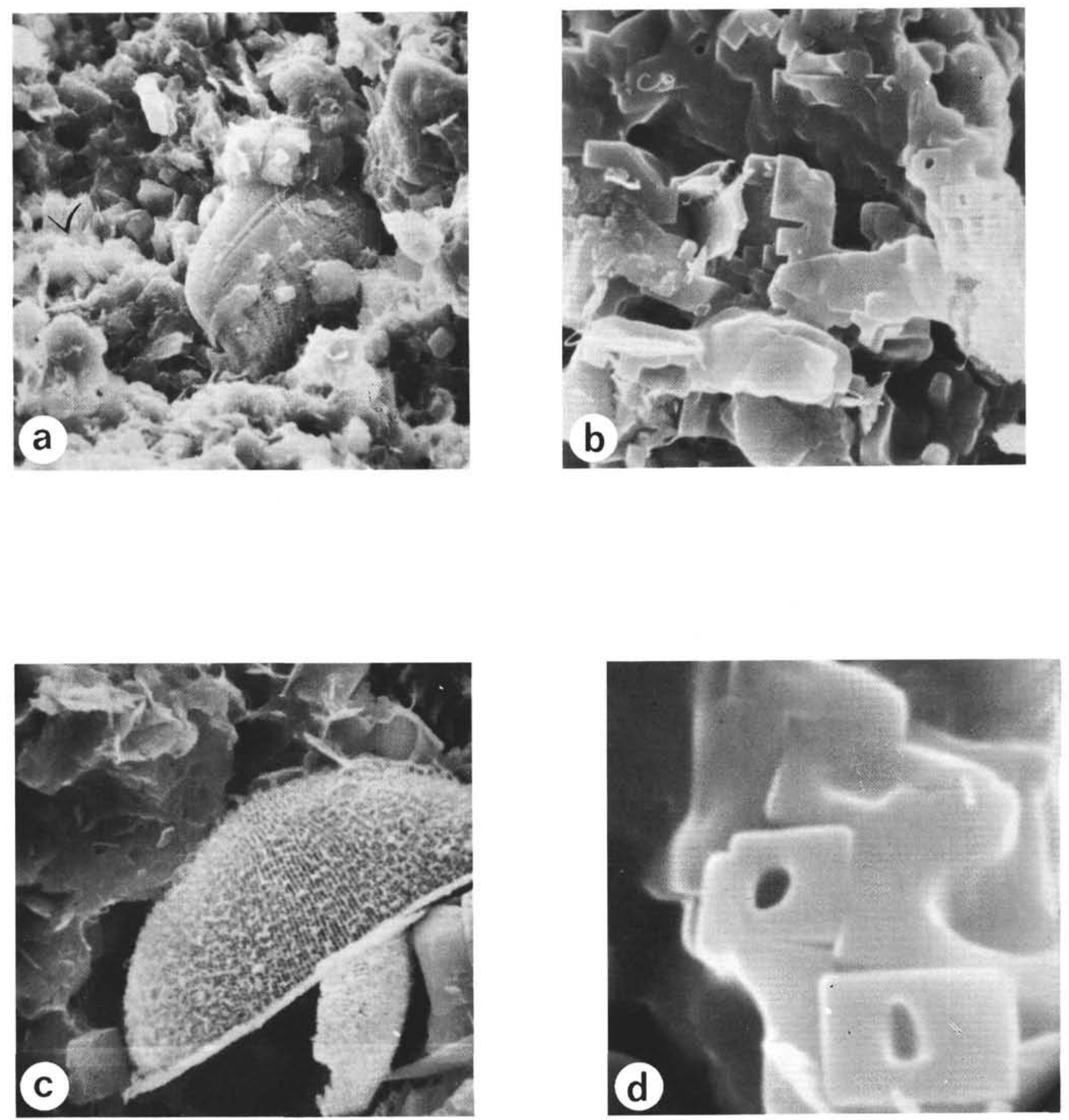

Figure 6. Small scale deformations in a dolomitic marl with gypsum of the top of the evaporitic series. These deformations are generally produced by the transformation of anhydrite to gypsum $(124$, core $7-1$, on scale).

$\mathrm{cm}$ thick, composed of large gypsum crystals. At the top, a layer of gypsum displaces the overlying marls, which display microfractures (Figure 7).

Core $6(362-365 \mathrm{~m})$, drilled 17 meters above Core 7 , is a dolomitic ooze. The sediment, stiff and laminated, is olive gray with interbedded thin, centimetric darker layers. It is made up of dolomite, quartz, clays, and small amounts of pyrite. The absence of calcite on the X-ray diffractograms is interesting. It is barren of fauna. Under the SEM, it seems to be composed mainly of small 3 to $5 \mu$ crystals of dolomite (Figure 8).

At Site 124, the contact with the overlying Pliocene open marine deposits was not cored. However the seismic reflection profiles show an angular disconformity, suggesting a hiatus (see Chapter 6).

The Abyssal Plain Near the Sardinian Margin (Site 134)

Site 134 is of interest in that it is the only one in which halite was recovered. Six holes were drilled on the subsided 


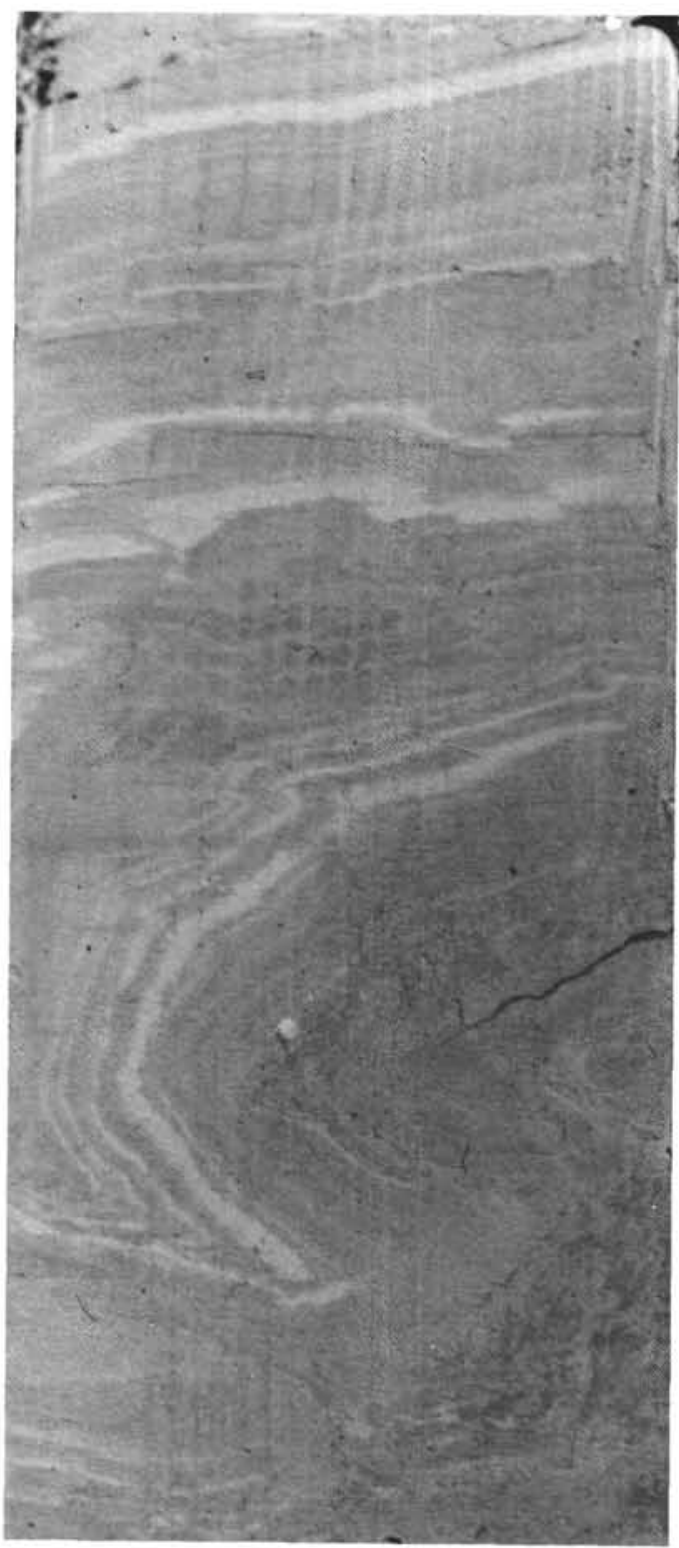

Figure 7. Laminated anhydrite. The rock consists of massive anhydrite displaying original bedding. This bedding was displaced by the growth of white nodules of anhydrite at the time the sediment was still soft $(124$, core 8 , on scale).

margin of the Sardinian block, which is buried under a blanket of sediment (see Chapter 14). Two of the holes reached evaporites. In Hole $134 \mathrm{D}$, situated on the continental margin, marls with gypsum were cored, while in Hole 134, positioned above the abyssal plain and oceanic basement, an important evaporitic series was recognized.

\section{Hole 134}

In Hole 134, 324 meters of pelagic oozes of Quaternary and Pliocene age overlie 40 meters of the evaporitic series. The lower half of this series contains thick horizons of alternating halite and anhydrite, interbedded with nanno oozes. Its upper half, of which only the top was recovered, consists of dolomitic marls with a marine fauna.

\section{Halite-Anhydrite Horizons}

Drilling bottomed in massive halite at 364 meters. Sequences of halite were first encountered in Core 8 , and then below in Core 10. In the later, a continuous section of massive evaporites, 1.6 meters long, was recovered. They consist mainly of halite, interbedded with thin layers of anhydrite. The halite beds, 10 to $30 \mathrm{~cm}$ thick (Figure 9), are massive, translucent rock salt, white to light gray in color. These beds of massive halite show regular bedding, 3 to $5 \mathrm{~cm}$ apart. The thin anhydrite intercalations, 1 to $5 \mathrm{~cm}$ thick, consist of white and gray laminae only millimeters thick. Many beds, both halite and anhydrite, show small scale deformations of diapiric type. The small section of halite, $30 \mathrm{~cm}$ thick, recovered in Core 8 , is similar to the rocks of Core 10.

Thick horizons of laminated anhydrite occur above halite in Cores 10 and 8 . In Core 10, we recovered $35 \mathrm{~cm}$ of millimetrically laminated white and gray anhydrite. In Core 8 , a five-centimeter-thick layer of white nodules, embedded in a gray matrix, interrupts the laminated sequence of anhydrite.

\section{Interbedded Marine Oozes}

Two horizons of marine oozes are interbedded with the massive salts. In Core 10, a bed of dolomitic ooze, $65 \mathrm{~cm}$ thick, occurs between the anhydrite and the halite. The ooze is bedded, plastic, and dark gray in color. It contains quartz, dolomite, clays, and trace amounts of halite and gypsum. The clay minerals are illite, interstratified clays, montmorillonite, and chlorite. Under the SEM, it shows small crystals ( 2 to $5 \mu$ ), among which recrystallized dolomite rhombs are recognizable (Figure 10). The fauna is poor and consists of nannoplankton and rare planktonic foraminifera together with ostracods, radiolarian debris, and sponge spicules. This assemblage suggests an open marine environment. When opened, the core gave off a strong methane-like odor. Shore-based laboratory study showed the presence of migrated hydrocarbons (see Chapter 32).

Core 9 recovered a small piece of foraminiferal sandstone of Messinian age. The rock is composed of abundant foraminifera, with quartz, mica, and a scanty nannoplankton fauna. It suggests a marine episode with flourishing planktonic life.

\section{Top of the Evaporite Series}

The boundary between the evaporitic series and the overlying pelagic oozes of Pliocene age was observed in Core 7, at 324.3 meters. The boundary is sharp and suggests an erosion surface. Light-colored pelagic oozes overlie dark colored dolomitic marls (Figure 11). The fauna indicates that a hiatus of approximately two million years occurs between the two lithologies.

The top of the evaporite series, of which a $45 \mathrm{~cm}$ section was recovered, consists of marl oozes and dolomitic marl oozes. These are laminated and display alternate lighter and darker hues of olive to dark gray color. Oblique bedding, indicative of bottom current action, microfractures, and microdeformations are present. X-ray analysis shows that 

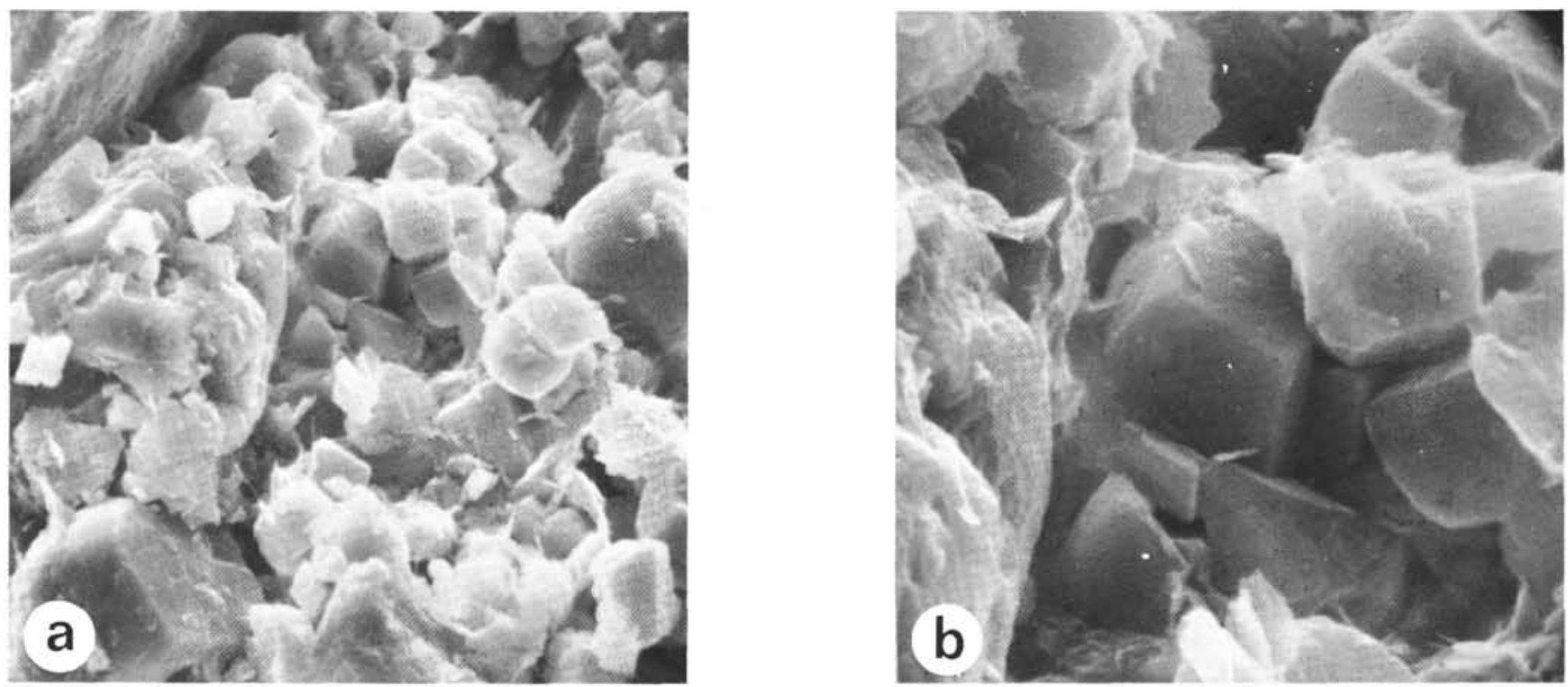

Figure 8. Dolomitic ooze near the top of the evaporitic series in Site 124 (Balearic Basin). The ooze comprises mainly small rhombohedral crystals of dolomite, 3 to 5 microns across, together with quartz and clays. It is barren and no calcite is present. The small size of the crystals suggests penecontemporaneous dolomite (124-6 CC, SEM, a $\times 2300, b \times 5600)$.

the laminated horizons are interbedded marl oozes (calcite only) and dolomitic marl oozes (calcite and dolomite). Besides carbonates, the oozes contain quartz, feldspar, halites, clays, and, in one sample, anhydrite. Clay minerals are dominantly montmorillonite, together with illite and chlorite.

The fauna is poor. The foraminifera are small sized, and the nannoplankton slightly overcalcified. The assemblage is of Messinian age.

\section{Hole 134D}

In this hole, situated on the edge of the Sardinian continental block, drilling first penetrated Quaternary and Pliocene oozes. At 175 meters, six meters below a hard horizon taken to be the Pliocene-Quaternary boundary, a first core was taken. It consists of a bedded silty marl ooze with large gypsum crystals (Figure 12a). The color is medium dark gray for the ooze and white for the gypsum nodules. The ooze contains quartz, calcite, feldspar, and clay minerals (Figure 12b). The gypsum is disseminated as small crystals in the bulk of the ooze and as large nodules (3 to $5 \mathrm{~cm}$ ) of saccharoidal gypsum. The silt consists of rounded quartz.

Information about the age of the marl ooze is not available. However, it lies directly on the semi-schists of the Sardinian margin. Higher on this margin, in holes $134 \mathrm{~A}$ and 134B, no evaporites were encountered. Thus the hole 134D marls may be interpreted as edge deposits of the Messinian evaporitic series of the Balearic Basin which were tectonically separated from the main formation during subsidence of the Sardinian margin. Alternatively, they may also be younger isolated lagoonal formations, representing an encroaching Pliocene sea.

\section{The Tyrrhenian Sea (Site 132)}

Site 132 is located in the deep central basin of the Tyrrhenian Sea. Here 182 meters of pelagic marl oozes of
Pliocene and Quaternary age overlie the evaporitic series, which were penetrated down to 223 meters.

The Messinian evaporite deposits contain horizons of massive gypsum interbedded with dolomitic marls and clays. A well-defined trend is noted in this sedimentary column. The benches of massive gypsum, dominant at the bottom, gradually disappear and are replaced by dolomitic clays and marls toward the top of the formation.

\section{Massive Gypsum}

Drilling bottomed in massive gypsum. The last core, 27 $(220-223 \mathrm{~m})$, recovered 2.5 meters of well-bedded and brightly colored rock displaying a succession of structures. At the bottom, bedding consists of wavy millimetric laminations characteristic of algal mats (Figure 13). The rock is yellow. To our knowledge, it is the first time that a replacement of algal mats by gypsum has been observed. Above $(27-2,32$ to $102 \mathrm{~cm})$, the wavy laminations are replaced by large nodules embedded in a cryptocrystalline matrix, the entire rock being dark red. Upward, a new laminated section of gray color $(27-2,12$ to $32 \mathrm{~cm})$ is overlain by a mosaic of coalescent centimeter-size gray nodules $(27-1,80$ to $150 \mathrm{~cm})$. The core is topped by a short section $(27-1,50$ to $80 \mathrm{~cm})$ of black and white centimeter-size beds separated by wavy boundaries (Figure 14).

In Cores 26 and 25, the horizons of massive gypsum are interbedded with plastic dolomitic oozes. In Core 26, we noted two beds of gypsum $30 \mathrm{~cm}$ thick. They are dark gray and finely laminated in millimetric darker and lighter layers which give a shaly character to the rocks (Figure 15). In Core 25 , a single bed $(25-2,92$ to $117 \mathrm{~cm})$ of yellowish brown massive gypsum was noted. It still displays the ghosts of its original laminations with, however, some well-delineated crystalline forms (Figure 16).

The last occurrences of massive gypsum were noted in Cores 23 and 22. In Core 23, which consists of plastic 


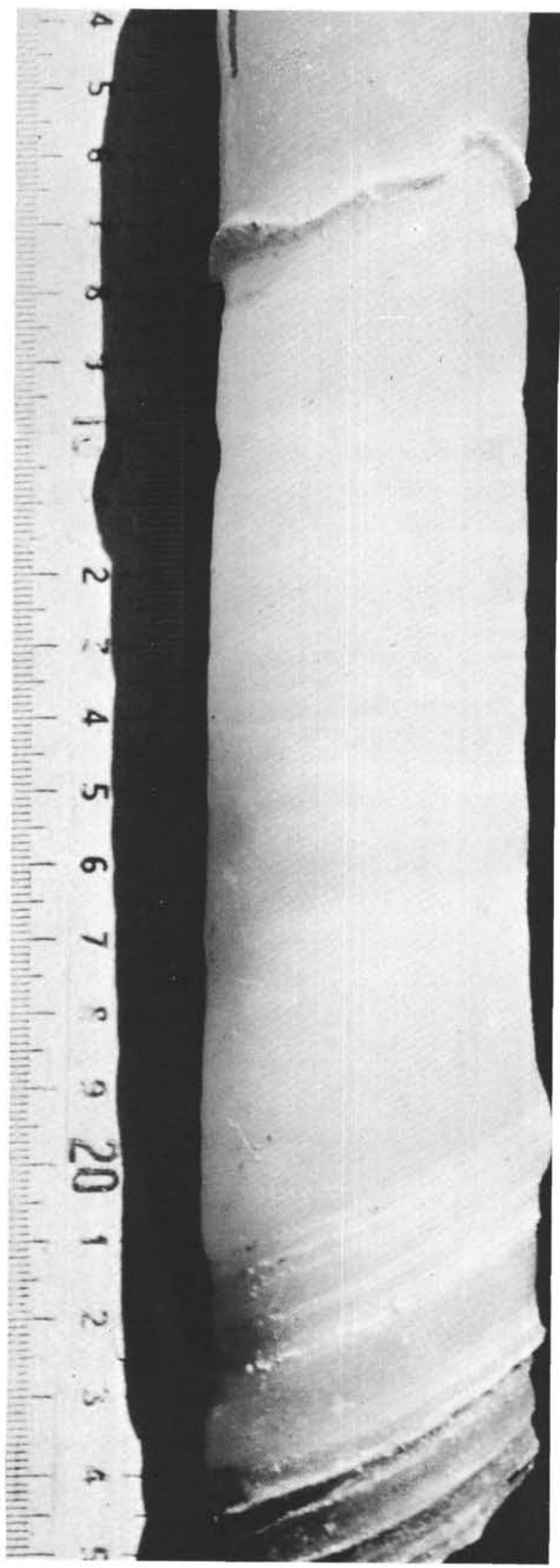

Figure 9. Halite with thin, millimetric interbeds of anhydrite. The halite is translucent and bedded. The anhydrite beds are light gray and nodular. Balearic Abyssal Plain, near the Sardinian margin (134-10-2). gypsiferous clay, a $5 \mathrm{~cm}$ piece of white saccharoidal gypsum, with wavy stromatolitic laminations, is interbedded near the top. A similar $12 \mathrm{~cm}$ piece occurs near the base of Core 22, but in the quite different context of only slightly affected marine mud ooze.

\section{Interbedded Clays and Marls}

The first plastic beds occur in Cores 26 and 25. They are 30 to $50 \mathrm{~cm}$ thick and display a large variety of colors: yellow, brown, red, green, black, etc. They are well-bedded to laminated. They contain mainly gypsum, with lesser amounts of quartz, feldspar, clays, and dolomite. The dominant clay mineral is montmorillonite, but illite, chlorite, interstratified clays, and trace amounts of kaolinite are also present. The carbonate content is low, 2 to 15 per cent. Only dolomite is present in addition to calcite. This composition classifies these plastic beds as gypsiferous dolomitic clays. SEM observations show the small size ( 2 to $4 \mu$ ) of the crystals making up this sediment (Figure 17). A scarce fauna is still associated with the sediment. It consists of a rich assemblage of planktonic foraminifera, but no nannoplankton were observed. This points out the advanced stage of replacement of the original marine ooze by gypsum and dolomite.

A bed of sandy clay occurs in the second section of Core $25(25-2,60$ to $87 \mathrm{~cm})$. It contains gypsum, quartz, feldspar, etc., and is colored dusky red, probably by hematite.

The first section of Core 25 differs from the underlying clays. It consists of light gray plastic and bedded ooze with closely spaced $(5-10 \mathrm{~cm})$ millimetric beds of crystalline gypsum (Figure 18). Isolated crystals of gypsum occur also throughout the bulk of the ooze. The sediment contains quartz, feldspar, the same clay minerals as in Cores 25 and 26 , and both calcite and dolomite. The accompanying fauna consists of foraminifera, without nannoplankton. This suggests an advanced, but not yet completed, transformation of the original marine ooze, some calcite still being present.

The next core, 23 (191-198 m), drilled fifteen meters above Core 25, recovered dominant gypsum with small amounts of quartz, suggesting an almost complete replacement of an original marl ooze by gypsum. As mentioned above, a layer of massive gypsum with stromatolitic structure occurs in the upper part of the core.

The top of the evaporite series (Cores 21 and 22, 182-191 m) includes interbedded sands and marl oozes. This sequence starts (base of Core 22) with a marine marl ooze containing quartz, calcite, and clays, but no dolomite. The sediment is light gray in color and is bedded. It is the first uphole occurrence of a non-affected, or only slightly affected, marine ooze (Figure 19). However, a piece of white massive gypsum with stromatolitic layering is interbedded near its base. Below this consolidated horizon, the marl ooze contains many large, millimetric gypsum crystals. Above this horizon, no gypsum or dolomite was noted in the marl oozes, with the exception of sandy layers. At the top of Core 22, this first true marine horizon is overlain by $40 \mathrm{~cm}$ of sandy clay.

The top of the formation (Core 21-2, 76 to $150 \mathrm{~cm}$ ) consists of a dark to light gray marl ooze with sand 


\section{W. D. NESTEROFF}
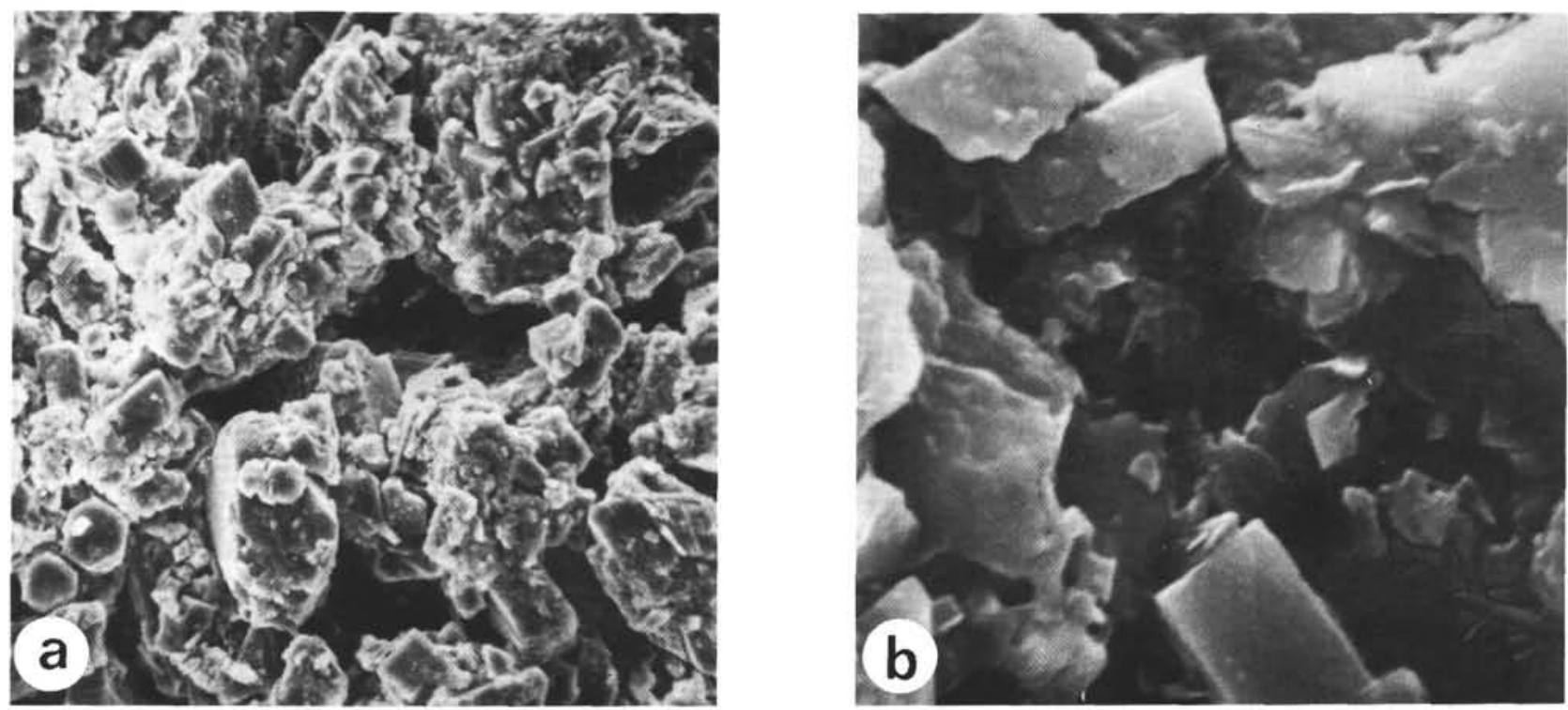

Figure 10. Marine ooze interbedded with massive salts. The plastic ooze comprises quartz, dolomite, clays, and a poor fauna. Under the SEM $(a \times 600, b \times 6000)$ the crystals are small sized: 2 to 5 microns. It suggests an open marine episode between the deposition of two layers of halite. This ooze contained migrated gas-range hydrocarbons (see Chapter 32). Balearic Abyssal Plain, near the Sardinian margin (134-10-1, $90 \mathrm{~cm}$ ).

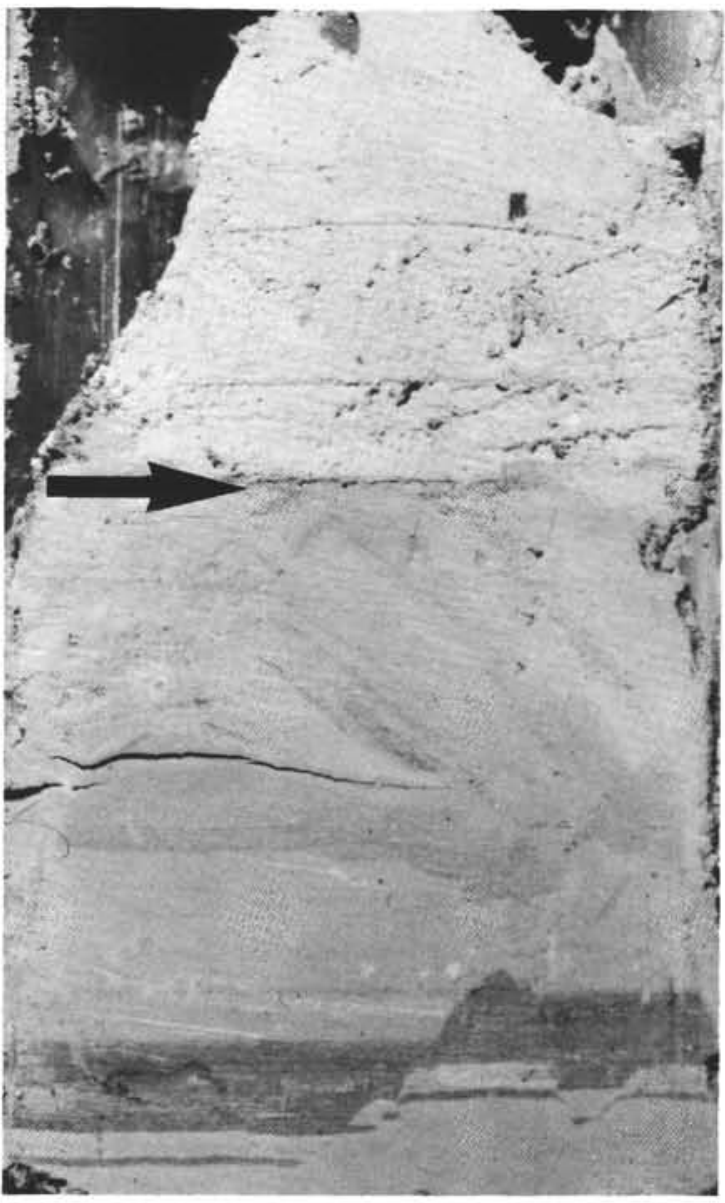

Figure 11. Miocene-Pliocene boundary at Site 134, Balearic Abyssal Plain. The light-colored Plio- cene pelagic nanno ooze overlay a darker Messinian marl ooze displaying microdeformations. The boundary is sharp and corresponds to an important hiatus (134-7-5).

interbedded at the top (Figure 21). The marl ooze is marine, containing a calcitic microfauna together with quartz, illite, interstratified clays, and montmorillonite. The fauna contains nannofossils, benthonic foramifera and a poor assemblage of planktonic foraminifera. It is a poor fauna suggesting a relict assemblage. SEM observations show, however, the beginning of the leaching of calcitic nannoplankton, i.e., the beginning of diagenesis (Figure 20).

Below the Pliocene boundary, the marl ooze is interbedded with sandy marls displaying oblique and cross-bedded laminae. The sand fraction includes angular quartz, feldspar, and gypsum. Small amounts (2\%) of dolomite occur together with calcite in the fine fraction of the sandy layers. The current marks and the presence of sands point to a coarse terrigenous input, and suggest transportation either in shallow water or by turbidity currents.

The top of the evaporite series is a sharp and erosional contact at 79.75 meters. Here lightly colored pelagic nanno oozes of lower Pliocene age, high in calcium carbonate, overlie the dark gray sandy marls of the terminal Messinian (Figure 21). However, as no stratigraphic gap occurs at the contact, this suggests a sudden change in sedimentary conditions rather than an important erosional period. 

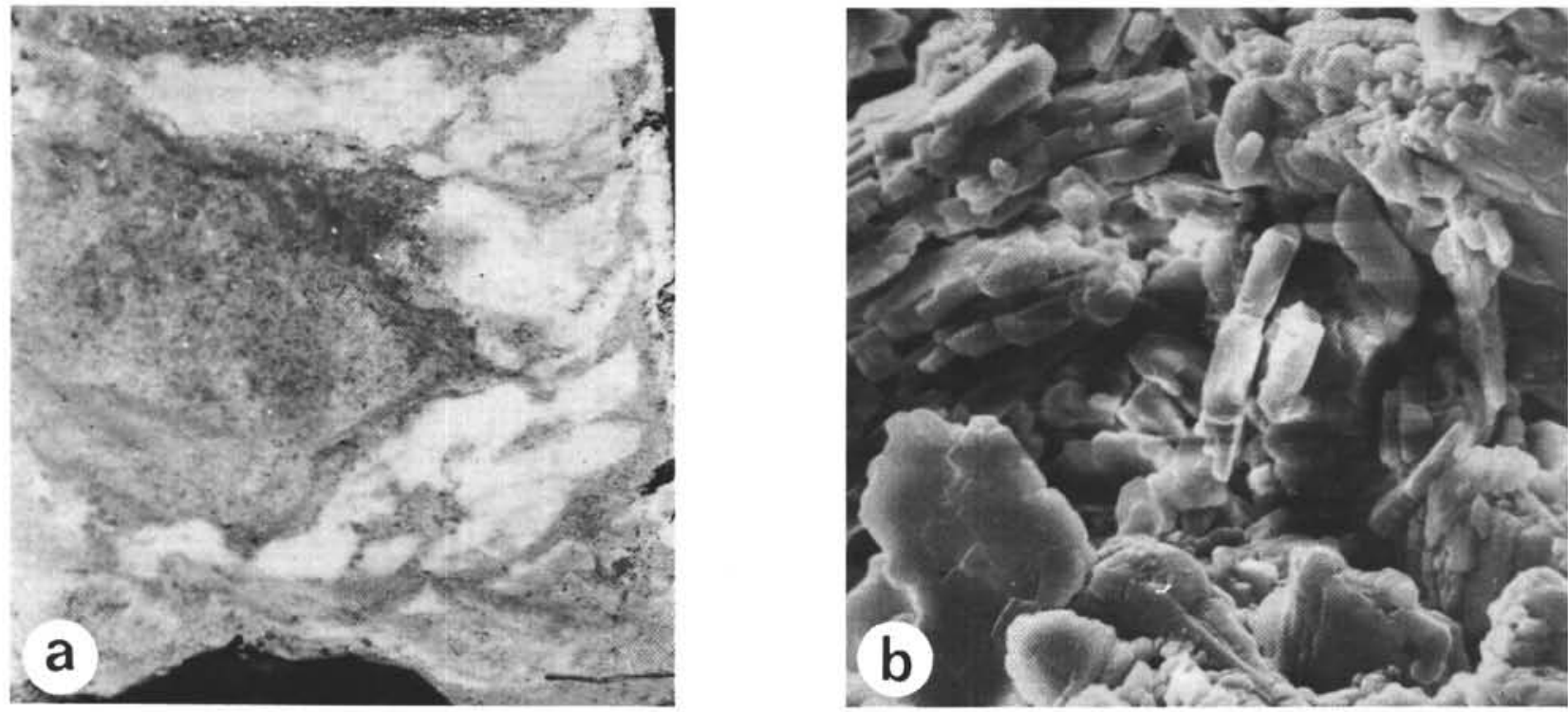

Figure 12. Marl ooze with gypsum crystals. Large nodules of saccharoidal gypsum have developed in the ooze, which contains no dolomite. Sardinian margin (134-1-1-125 cm) a: on scale, b: SEM $\times 2400$.

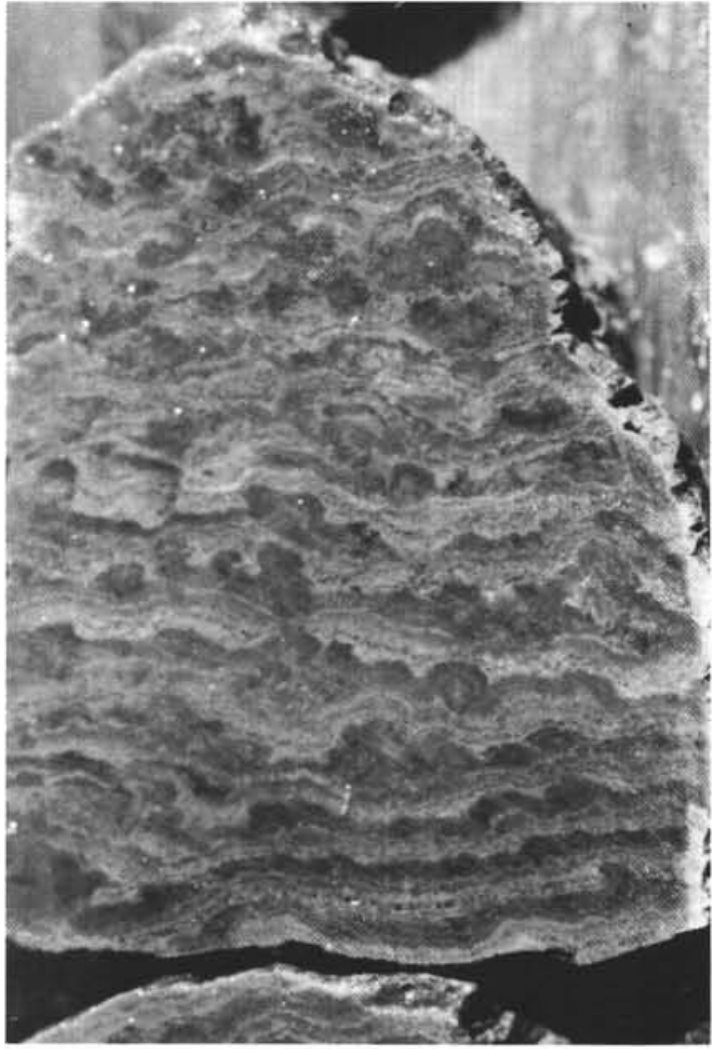

Figure 13. Massive Gypsum. The rock displays wavy laminations characteristic of algal mats. Tyrrhenian Sea $(132-27-2,102-110 \mathrm{~cm}$, on scale).

\section{The Mediterranean Ridge - Sites 125 and 126}

\section{Site 125}

This site is located on the ridge, in a cobble zone. A blanket of 80 meters of pelagic marl and nanno oozes, Pliocene and Quaternary in age, overlies the Messinian evaporites.

The evaporitic series was penetrated between 79.75 and 121 meters, where drilling bottomed on a hard horizon. The drill bit was plugged by a piece of white saccharoidal gypsum believed to be representative of the hard horizon. This rock was packed with dolomitic clay and also contained lenses of saccharoidal gypsum.

Forty meters of Messinian evaporites overlie the hard stringer of gypsum. All cores recovered from this interval (9A, 8A, 7A and base of 6A) consist of dolomitic clay. The sediment is dark gray, plastic to stiff and laminated. It is poor in calcium carbonate, 20 to 25 per cent, and contains quartz, minute "oolitic" dolomite crystals, and clays. The latter contain illite, interstratified clays, montmorillonite, kaolinite, and chlorite.

The evaporitic formation is topped (at $79.75 \mathrm{~m}$ ) by a 7-cm-thick layer of almost pure, fine-grained dolomite. The rock was found in the core liner broken into small, angular pieces $(3-5 \mathrm{~mm})$ embedded in a matrix of watery clay. The freshness of the fractures suggests an original layer of solid dolomite crushed during drilling. The absence of displaced pieces of dolomite above and below this interval suggests, on the other hand, that the original horizon was not noticeably different in thickness from the recovered layer. The sharp upper boundary of this dolomite, directly overlain by open-sea pelagic sediments of lower Pliocene age, suggests the formation of a crust prior to the sudden Pliocene transgression. A hiatus of at least one million years separates the two lithologies. 


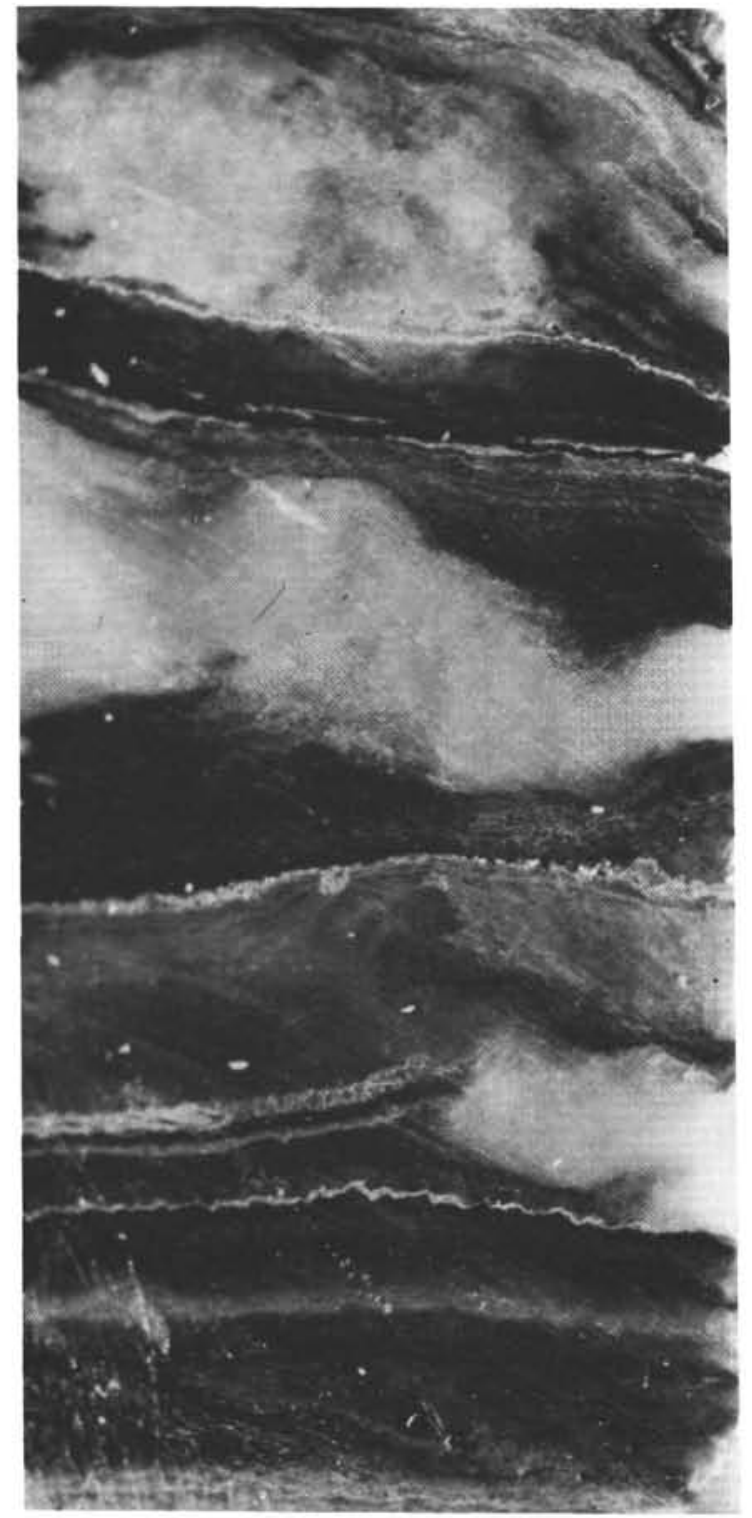

Figure 14. Massive gypsum. Black and white beds separated by thin wavy boundaries. Tyrrhenian Sea (132-27-1, 50-80 cm, on scale).

The dolomitic clays are barren except in the upper and lower drilled horizons. The mud, containing gypsum recovered on the drill bit, contains a scarce fauna of planktonic foraminifera of Messinian age, together with diatoms and sponge spicules. This assemblage suggest a shallow-water or lagoonal environment.

At the top, immediately below the dolomitic crust (base of Core 6 and core catcher), an unusual assemblage was observed. This consists of scattered, dwarfed planktonic, and rare benthonic, forminifera, the latter being true shallow-water and littoral forms. Some of the benthonic foraminifera show evidence of transportation. In some horizons, spores and organic matter are abundant.

\section{Site 126}

This site is located northeast of Site 125, in a deep cleft eroded into the Mediterranean Ridge. Drilling penetrated

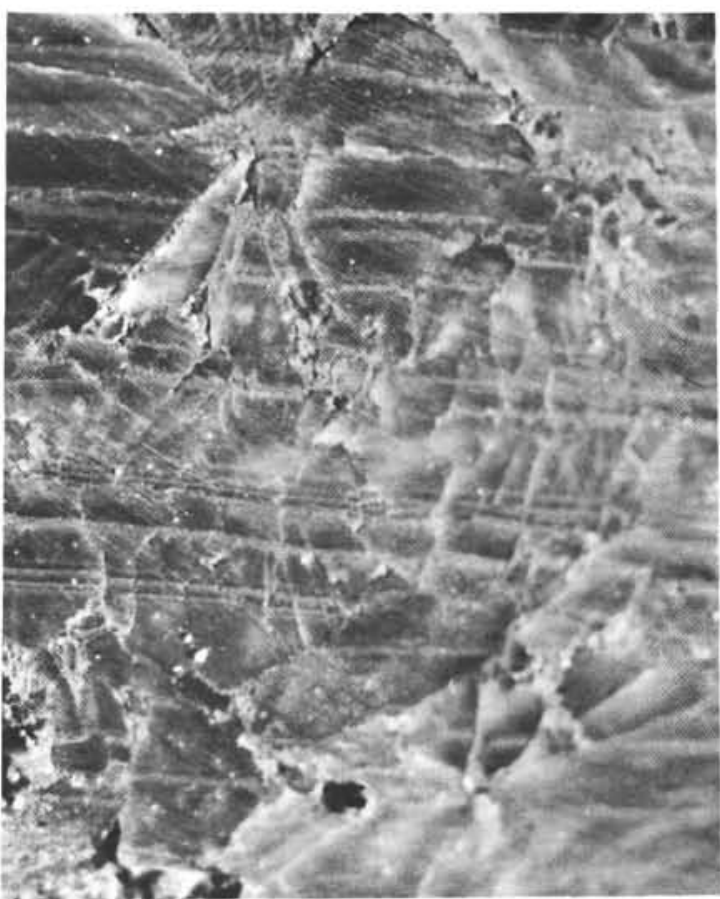

Figure 15. Massive gypsum replacing an ancient bedded ooze. The rock is still shaly. Tyrrhenian Sea (132-26-1, 128 to $135 \mathrm{~cm}$, on scale).

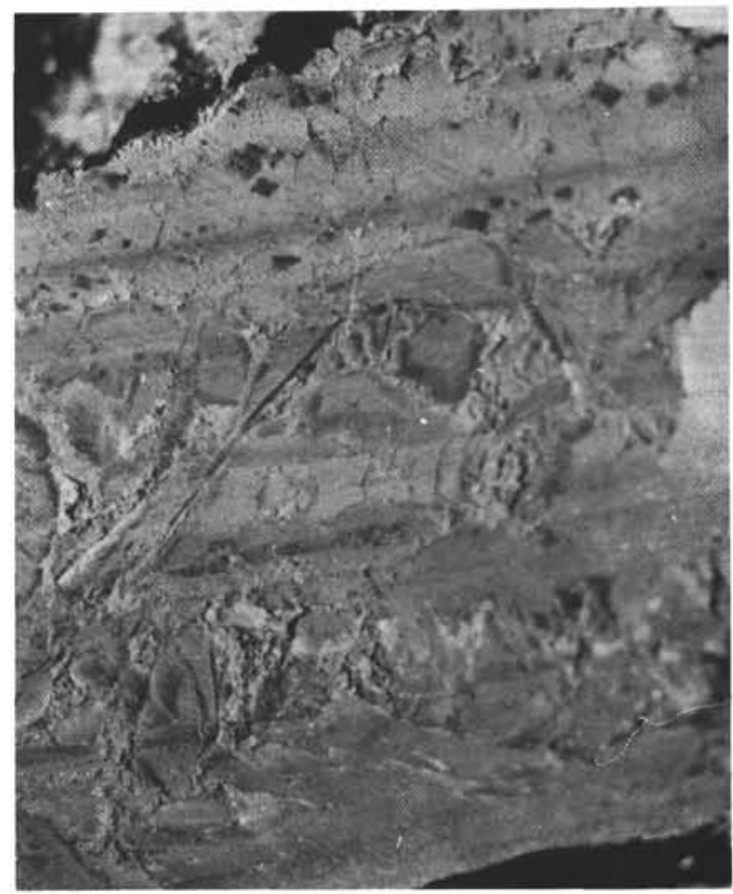

Figure 16. Massive gypsum. The rock still displays the ghosts of the original bedding. The growth of large gypsum crystals obliterated this bedding at a time when the original sediment was still soft and presumably not completely replaced by gypsum. Tyrrhenian Sea (132-25-2, 95 to 100 $\mathrm{cm}$, on scale). 

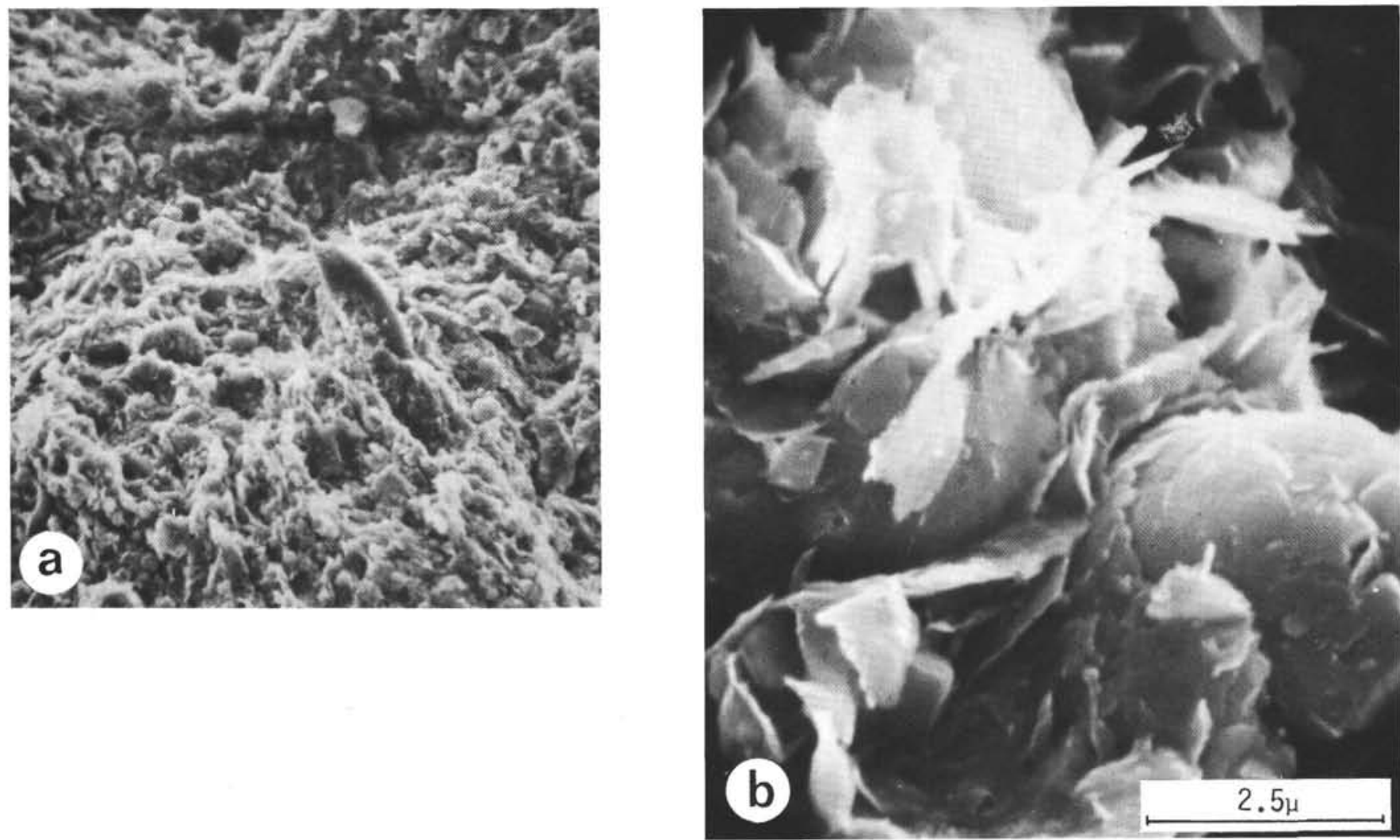

Figure 17. Beds of plastic gypsiferous dolomitic clay interbedded with massive gypsum. The plastic beds comprise mainly gypsum crystals together with quartz, clays, and dolomite. Note the sheet-like aspect under the SEM. Tyrrhenian Sea $(132-26-1,80 \mathrm{~cm}, a \times 600, b \times 12,000)$.

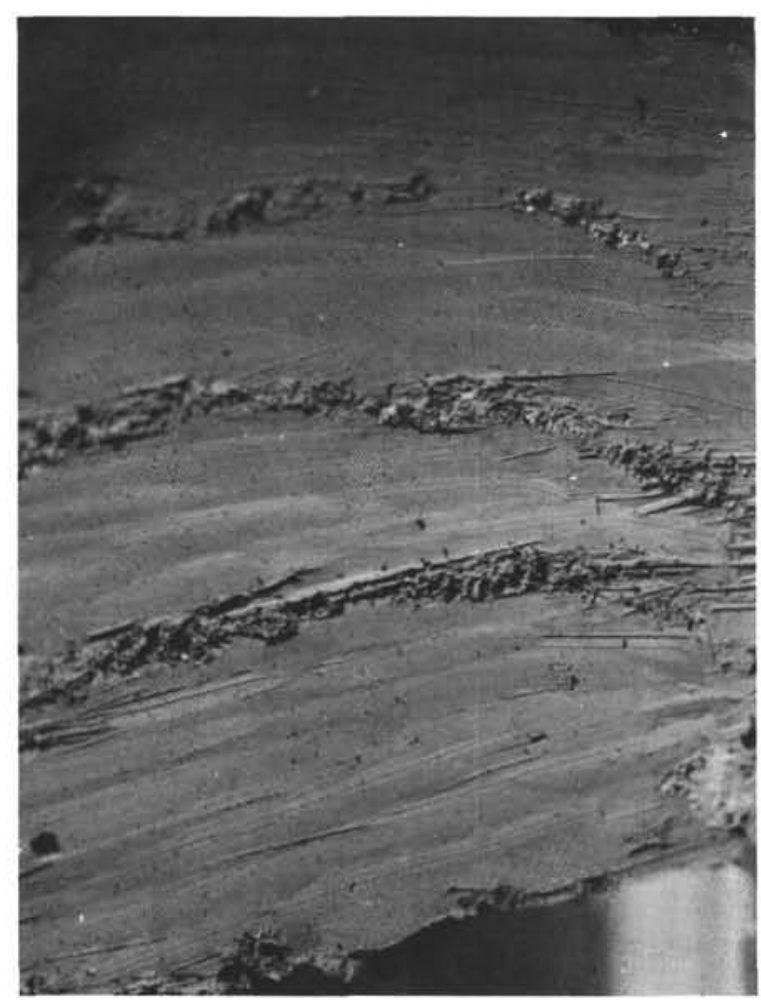

Figure 18. Dolomitic marl ooze with millimetric beds of gypsum. Originally the ooze was marine. Some foraminifera are still present but the nanno- plankton disappeared testifying to the advancement of the replacement processes. Tyrrhenian Sea (132-25-1, 0 to $25 \mathrm{~cm}$, on scale).

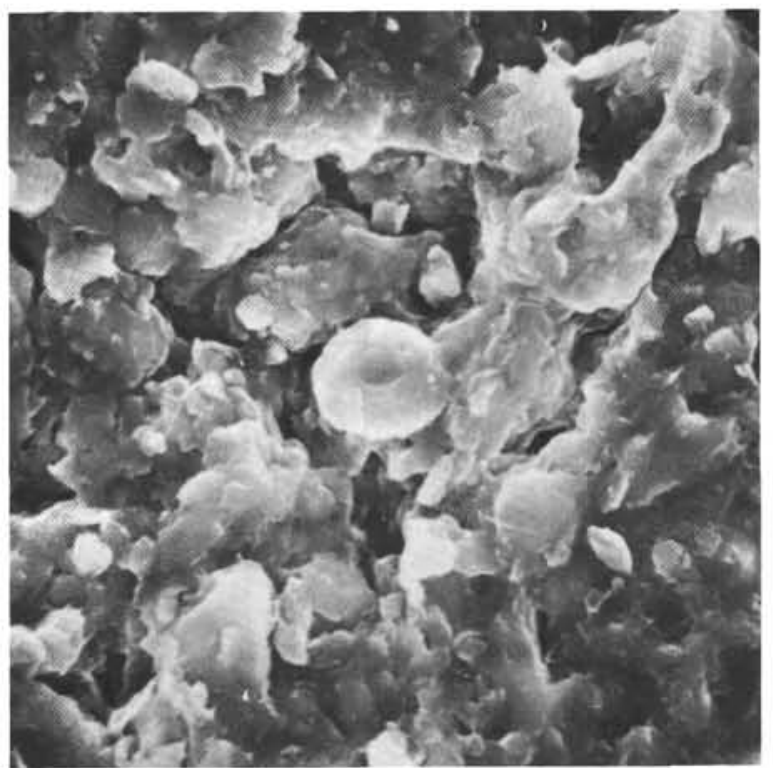

Figure 19. Marl ooze of the top of the evaporitic series. This ooze shows no transformations: neither dolomite nor gypsum are present. Tyrrhenian Sea (132-22-1, $110 \mathrm{~cm}$, SEM $\times$ 600). 

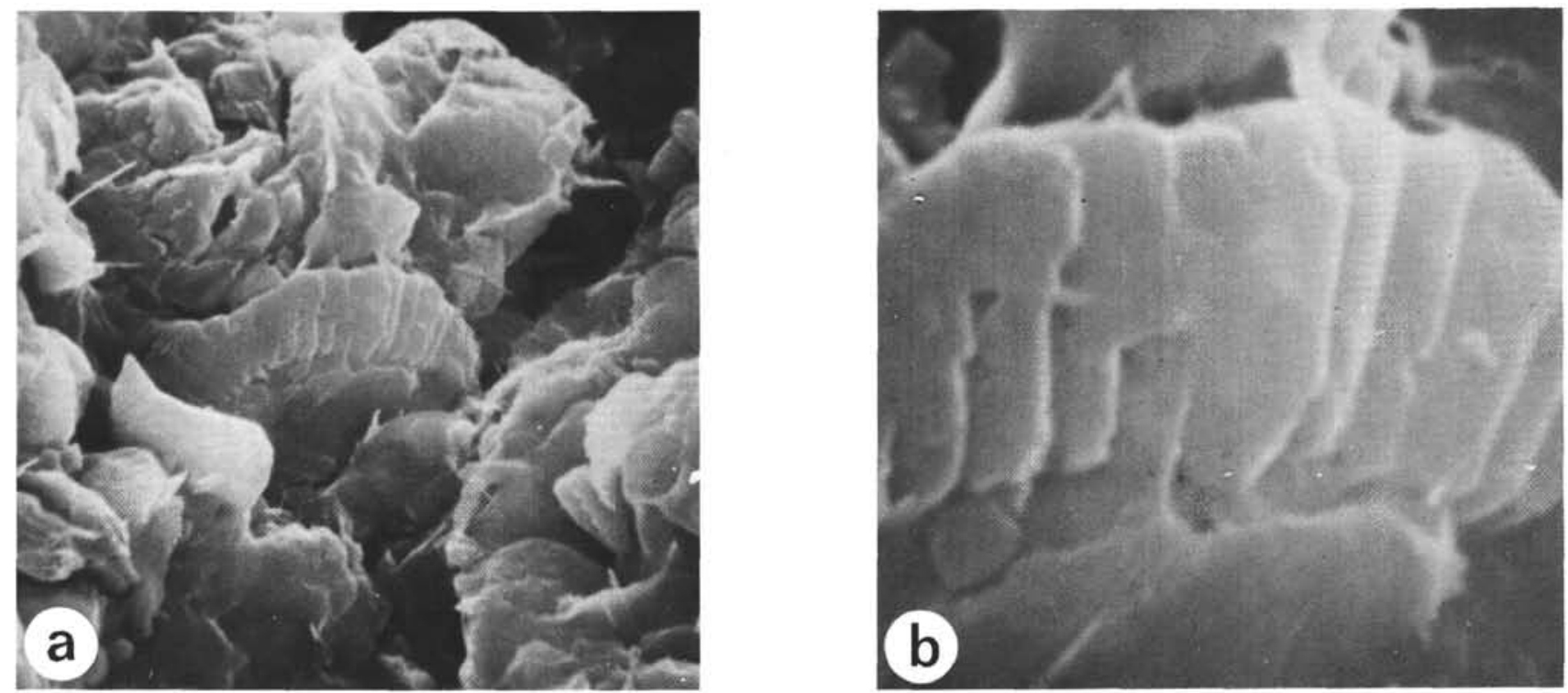

Figure 20. Marl ooze of the top of the evaporitic series displaying a beginning of replacement. $X$ ray indicates small amounts of dolomite (2\%) but no gypsum, and SEM show a partial dissolution of the calcareous nannofossils (Figure b). Tyrrhenian Sea (132-21-2, $141 \mathrm{~cm}$, SEM: $a \times 5500, b \times 22,500)$.

106 meters of the Quaternary valley before reaching bedrock, Serravalian marls. The Quaternary deposits consisted of turbidites containing occasional gravels (Site 126 , Core 2, Sections 1,2, and 4). These gravels consisted of dolomitic clay, very similar to the sediments of the Site 125 evaporitic series.

As the seismic profiles have shown that the evaporitic series outcrop in the walls of the cleft, the gravels were probably eroded from these outcrops prior to redeposition by turbidity currents.

\section{Strabo Mountains (Site 129)}

Site 129 is located at the foot of the northern slope of Strabo Mountains. The three holes penetrated a complex pile of terrains in apparent or real abnormal superposition. Tectonic disturbances may have been responsible for the observed situation (see Chapter 10).

The occurrence of late Miocene deposits is suspected in Hole 129, but not proven. On the other hand, Cores 2 and 3 of Hole $129 \mathrm{~A}$ were definitely assigned to the Messinian (see detailed discussion in the biostratigraphy section of Chapter 10).

In the core catcher of Core 129A-2, we recovered two pieces of ooze and a fragment of rock. The first two pieces, labeled "a" and "b," are plastic dolomitic marl oozes. They differ slightly in color, one being olive gray and the other dark greenish gray. Both are bedded, with orange hues marking the laminae. They contain calcite and dolomite, quartz, feldspar, pyrite, and, of the clay minerals, illite, montmorillonite, and chlorite. The coarse fraction consists of angular quartz and a poorly diversified fauna of dwarfed foraminifera. There are abundant specimens of the benthonic foraminifera Ammonia beccarii tepida and of the ostracod Cyprideis pannonica. This assemblage is characteristic of brackish water and is almost identical to the one observed in the Marne argillose inferiori of Sicily (Selli, 1960).
The last piece, labeled "c," is an indurated dolomite. It is barren of fauna and greenish gray in color. The scanning electron microscope shows large $(100 \mu)$ euhedral rhombs of dolomite (Figure 22; see also Gervitz, Chapter 24.2).

Core 129A-3 consists of a silty dolomitic marl ooze. The sediment is gray and shows a well developed oblique, crossed, and even folded, bedding. It contains dolomite and calcite, together with quartz, feldspar, and clays. The bedding is marked by concentrations of silts and biological degris. The brackish-water fauna is similar to the one from Core $2 \mathrm{~A}, \mathrm{CC}$, pieces a and $\mathrm{b}$.

\section{GEOGRAPHICAL DISPOSITION AND STRUCTURE OF THE EVAPORITIC MEDITERRANEAN BASINS}

The geographical distribution of the evaporites is quite distinctive. It roughly coincides with the actual deepest zones of the western as well as of the eastern basins (Figures 1 and 2). In the western basin, the diapiric strata revealing the presence of halite are located in a central deep demarcated by a sudden plunging of the continental blocks (Glangeaud et al., 1966). This deep quite possibly represents an oceanic bottom which is quite different from those of the areas that surround it (Fahlquist et al., 1969, Ryan et al., 1971). The seismic reflection profiles reveal that the evaporitic formations reach a thickness of 500 to 2000 meters. Between the base of the evaporites and the ocean bottom, one can observe as much as $1.5 \mathrm{~km}$ of sediments in the center of the basin (Falquist et al., 1969; Ryan et al., 1971, refraction profiles No. 5 and 194).

Our drillings have allowed us to date the evaporites as Messinian. It is now possible to propose an age for the central oceanic trough, i.e., for the oceanization of the western basin. What we still lack, however, is knowledge of the nature of the sediments under the evaporites. They may also consist of pelagic deposits, the rate of accumulation of which (compaction included) is about $3 \mathrm{~cm} / 10^{3} \mathrm{y}$, or turbidites, the rate of accumulation of which is much 


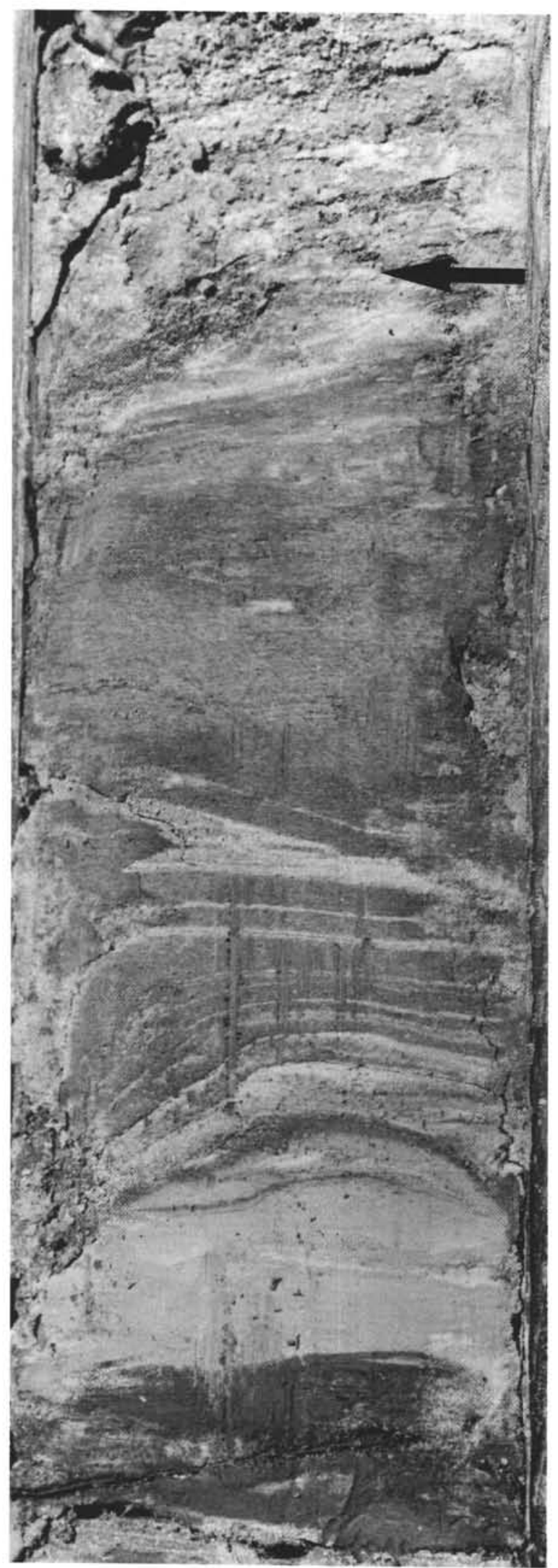

Figure 21. Figure a. Pliocene-Miocene contact in the Tyrrhenian Sea Site 132. The top of the evaporitic series consists of dark gray sandy marl oozes displaying oblique laminations and comprising a dwarfed fauna. It is overlain with a sharp contact by a light-colored open-sea pelagic nanno ooze. No stratigraphic gap occurs at this contact (132-21-2, 75 to $105 \mathrm{~cm}$, on scale).

higher, averaging 20 to $25 \mathrm{~cm} / 10^{3} \mathrm{y}$. In any case, for a deposit of $1.5 \mathrm{~km}$ of pre-Messinian sediments, one may propose a bracket between 50 my for pelagic sediments and 15 my for turbidites. This range is quite large and permits one to consider many tectonic phases during the Tertiary. A body of geological data, including the behavior of the blocks during the compressive phases, the regressions and transgressions, and so forth, suggest, however, that the opening of this oceanic trough occurred at a rather late period. The great thickness of the sediments contained may then be explained either by the fact that it is entirely filled with turbidites, or by the fact that the rates of the pelagic deposits have been exceptionally high, as, for example, is the case of the Quaternary deposits at Site 121 (19 $\left.\mathrm{cm} / 10^{3} \mathrm{y}\right)$.

Under these conditions, the oceanization of the Mediterranean may have happened about 30 my ago. We only know of a single phase of distension affecting Europe at that time. It is the one that took place in the lower Oligocene (Cogné et al., 1966), following the AlpinePyrennean orogenic phase.

It is interesting to compare the data concerning the central trough of the western basin with the existing data for other basins throughout the world. If we plot heat flow versus mean depth we find that the plot falls in the area corresponding to normal mid-ocean spreading centers (i.e., the shaded area of Figure 6; Sclater, 1972). In addition, a plot of heat flow versus mean depth, corrected for isostatic loading, when compared to known examples, indicates an age of from 20 to 30 my (Sclater, 1972, and personal communication). This suggests that the central trough of the western basin of the Mediterranean is similar to a normal oceanic spreading center.

Since the opening of the trough, accompanied by the creation of an oceanic sea floor, the center of the western basin has sunk, while its margins were rising. At the present time, as the Bouguer anomalies reveal, the bottom of this basin is in general isostatic equilibrium, one might be persuaded that this equilibrium could have been reached while following a regular subsidence rate from the opening to the present, and that only a convulsive movement, corresponding to the disappearance of the water in the Messinian might have disturbed the regular subsidence of the center and of the basin margins. A large body of geological data (to be examined later) lead us, on the contrary, to believe that this subsidence occurred in an extremely irregular way. The reasons for the delay in reaching a balance must then be sought while recognizing that the Mediterranean is made up of relatively small basins, and that considerable horizontal stresses are exerted upon them.

This being so, the western basin could have remained shallow up to the Messinian. It would only be from the Pliocene onwards that an important subsidence might have affected this basin and given it its topography. The eastern basin should have had a similar history, though it is yet difficult for us to state definitely the age of its ocean crust. 

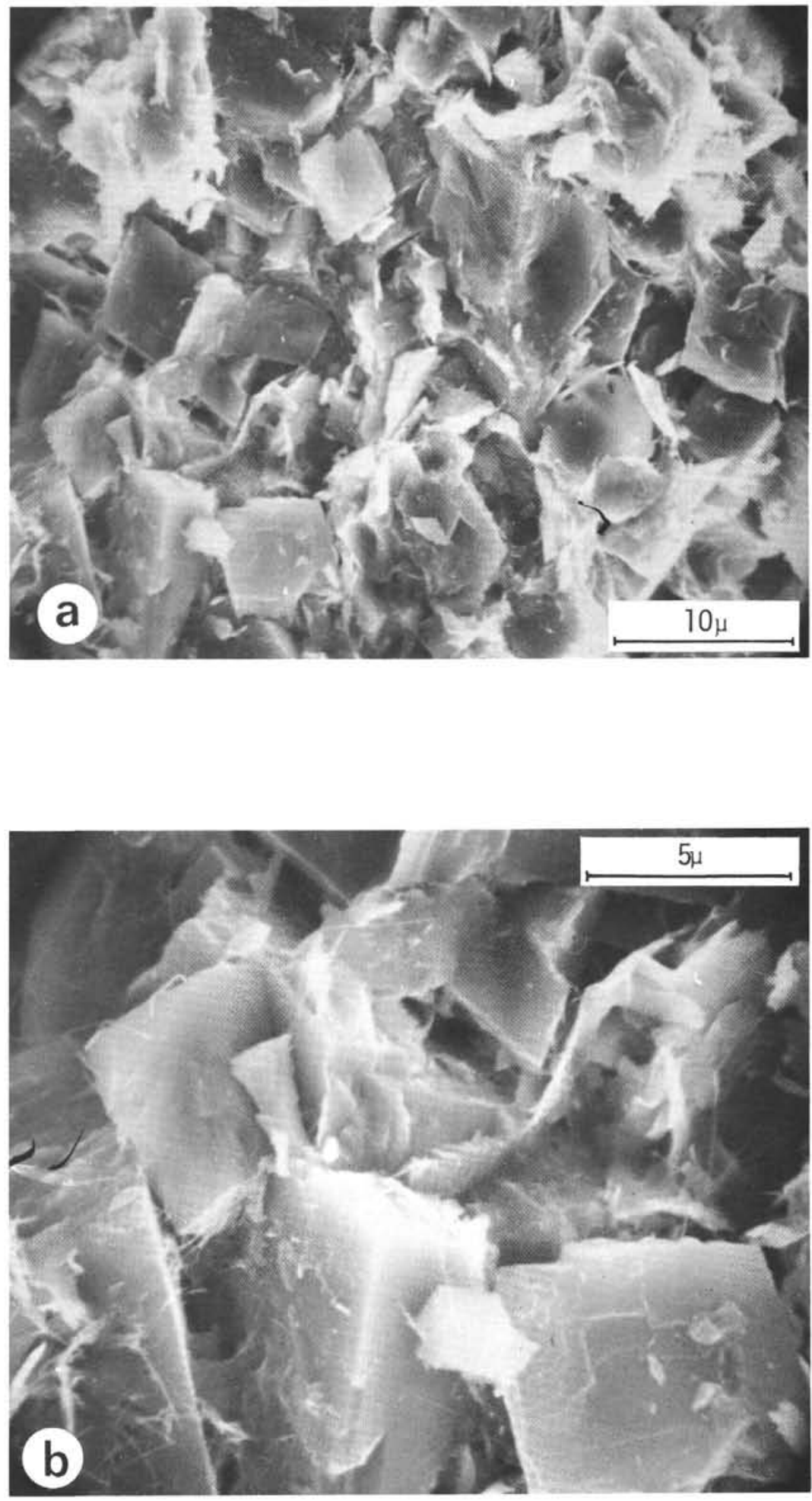

Figure 22. Dolomite from the base of the evaporitic series from the Strabo Mountain. The rocks are made up of large 100 micron rhombs, suggesting secondary dolomite (129A-2, CC, SEM: $a \times 2200, b \times 5250)$. 
Finally, although its bottom is of a continental or intermediate type (Heezen et al., 1971), the Tyrrhenian Sea would have similarly remained shallow up to the Messinian, before a subsidence that was to take place from the Pliocene onwards. Figure 23 is a tentative reconstruction of the Messinian evaporitic basins in the Mediterranean area.

\section{DISCUSSION}

The first problem concerning the Mediterranean evaporites is to find clues permitting us to decide whether they were deposited under shallow or deep-water conditions. A second problem, which may be implied, is that of the depth of the basin in which the deposit is forming. In this part we will therefore examine to what extent the cores that have been recovered in the course of Leg 13 may support the different hypotheses.

\section{The Problem of Shallow- or Deep-Water Evaporites}

When we first encountered evaporites in the Valencia Gulf, we could not ascertain whether we were observing shallow- or deep-water deposits. However, as drilling proceeded, we kept accumulating information that has since been reinforced by shore-based laboratory analyses. This information is of very diverse nature; petrographic, mineralogical, structural, faunal, isotopic, and so forth, but all the evidence converges to indicate that the evaporites have settled in a very shallow environment. We shall consider them below.
In the three sites $(124,132$, and 134) where thick, solid salt layers were penetrated, we observed laminated or stromatolitic structures. In the Balearic Basin (Site 124), they consist of laminated anhydrites within which nodules have developed and displaced overlying strata (Figure 7). These, in turn, cover nodular anhydrites which present a chicken-wire pattern (Figure 2). On the Sardinian margin (Site 134), they consist of laminated anhydrites similar to those of Site 124, but the last ones cap halite layers. In the Tyrrhenian Basin (Site 132), gypsum finally presents the undulated laminations characteristic of stromatolitic reefs.

In Recent deposits (Sabkhas of the Persian Gulf, Tunisia, Bahamas, Baja California, and so forth) the origin and development of the nodules has been very thoroughly described. These nodules form in carbonate sediments above the water table and displace the overlying sediment (Murray, 1964). Such is the case at Site 124, Cores 8 and 9, and at Site 134, Core 8. At a more advanced stage, the nodules grow, coalesce (penemosaic texture of Rooney and French, 1968) and then terminate by merging into one another (enterolithic structures of Shearman 1966, Shearman and Fuller 1969). Each stage, from the isolated nodules to the chicken-wire lattice structures, is displayed at Site 124 , Cores 8 to 13 .

Bluish green algal mats or stromatolites have likewise been described in the Persian Gulf, the Red Sea and so forth (Shinn et al., 1965; Textoris and Carozzi, 1966; Friedman and Sanders, 1967; Friedman, 1969; and others).

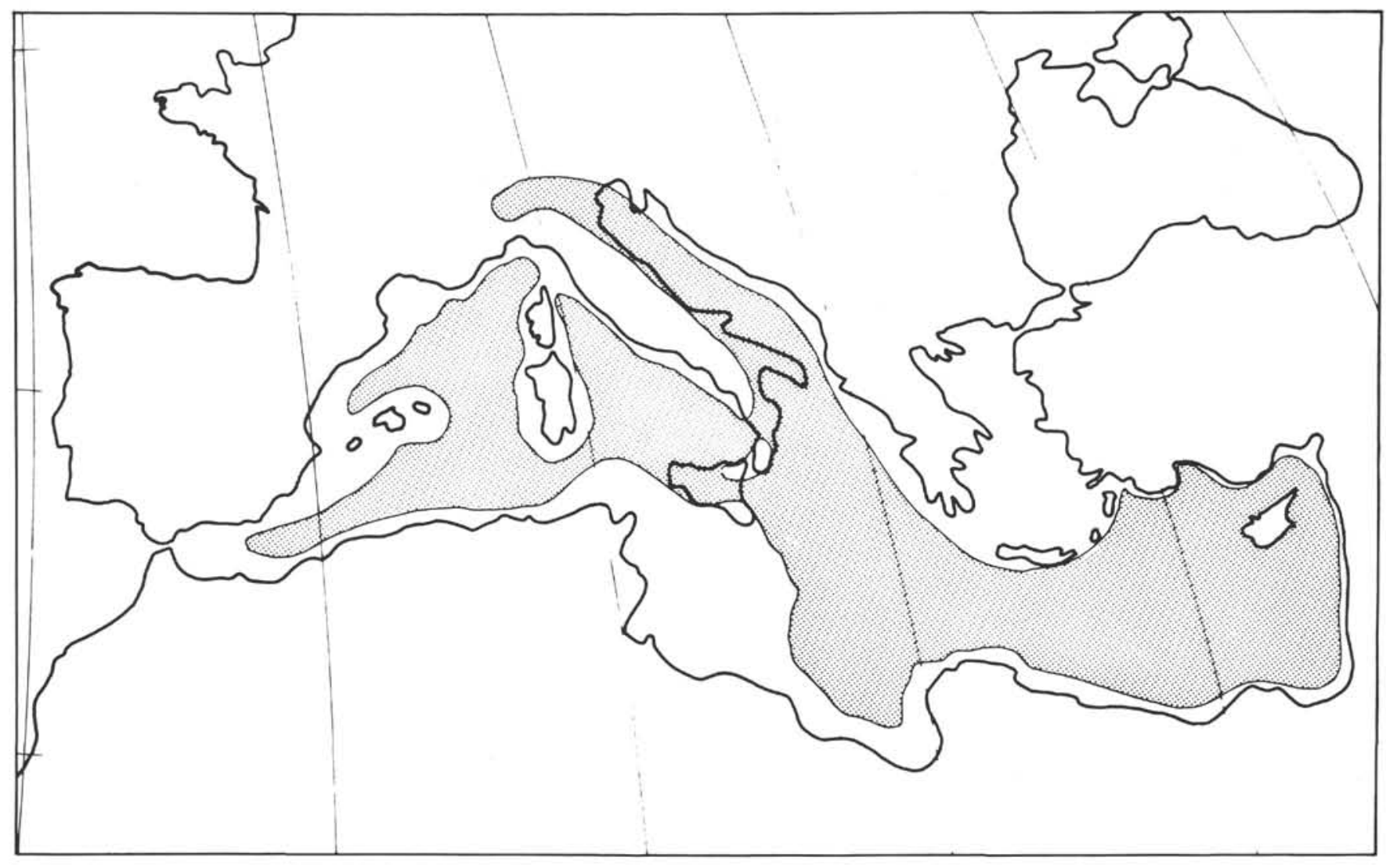

Figure 23. The distribution of the evaporitic formation in the Mediterranean area of the end of the Messinian. A tentative sketch. 
They consist of superficial films of algae that trap carbonate sedimentary particles. The carbonate is replaced later either by anhydrite or by dolomite (Lambo 1964, Rooney and French 1968). We have observed these stromatolitic structures in the Balearic Basin (Site 124, Cores 9 and 10) as well as in the Tyrrhenian Sea (Site 132, Cores 23, 26, and 27). All of these observations lead us to believe that the mode of formation of the laminated, nodular, and stromatolic textures discovered in the course of our drillings is analogous to that of the sabkhas and tidal flats of the present warm seas.

We also make these observations in light of the fact that a number of authors (e.g., Hardie and Eugster, 1971) consider anhydrites with parallel laminations as having been deposited on tidal flats by periodical storms. Laminated anhydrites were seen at Sites 124 (Cores 8 and 9) and 134 (Core 8 ) above nodular textures.

Littoral or brackish benthic microfaunas generally suggest the presence of a thin water layer. We have documented these faunas in our descriptions. In the Strabo Mountains (Site 129), the first Messinian strata contain shallow-water benthic foraminifera and brackish-water ostracods. In the Ionian Sea (Site 125), the basal evaporites contain abundant shallow-water benthic foraminifera. In the Balearic Basin (Site 124), some horizons of the evaporitic series contain laminae of diatoms (Cores 10 to 13). The pennate diatoms (Figure 5), together with the radiolaria that constitute these layers, suggest a brackishwater or marine environment.

The presence of dolomite always presents the problem of its origin. We know, of course, of a small number of modern examples of deep-sea dolomites (e.g., Peterson and Edgar, et al., 1970). All of these deep-sea dolomites, however, seem to represent exceptional cases. In modern seas, the conditions responsible for deposition of dolomite on a large scale are not realized (Strakhov, 1969, Garrels and Christ, 1964).

Virtually all the interstratified oozes encountered in the evaporitic series drilled are either wholly, or at least partially, dolomitized (Figure 1). Generally speaking, the replacement is well advanced, the proportion of only partial dolomitization is small, and only one example of a slightly dolomitic marl ooze has been observed (Site 125, drill bit). Moreover, the majority of these layers still contain some nannoplankton and foraminifera. For example, at Site 132, when one progresses down the evaporitic series, all the calcitic organisms disappear; nannoplankton first, then foraminifera. At the same time, the proportion of dolomite becomes higher. Finally, only dolomite is present from Core 25 downward. This shows that the plastic strata were originally marine oozes which were deposited between evaporitic periods.

This introduces the problem of the nature of the dolomite. Is it a primary or a secondary dolomite? The SEM observations show them to be constituted of extremely small ( 2 to 5 micron) crystals (Figures 4,5 , and 22). X-ray diffraction shows the presence of ordered dolomites (Goldsmith and Graf, 1958). These characteristics tend to indicate that they are penecontemporaneous dolomites. Isotopic analyses $\left(\delta \mathrm{O}^{18}\right.$ and $\left.\delta \mathrm{O}^{13}\right)$ amply confirm this point of view, since they establish that these are "very early diagenetic sediments" (Fontes et al., Chapter 30.2).

However, the mode of formation is not very clear. Probably the "marine" episodes originally led to the deposition of marl oozes made up of nannoplankton and foraminifera, i.e., calcite with quartz, clay minerals, etc. Therefore, dolomitization could only have taken place during evaporitic episodes. This view is strengthened by the opinion of Goldsmith and Graf (1968), who postulate that higher salinites promote the crystallization of ordered dolomite, as well as that of Degens and Epstein (1964), who consider that sedimentary dolomites have a $\mathrm{C}_{\mathrm{A}} \mathrm{CO}_{3}$ precursor. These viewpoints are not universally accepted, and the Leg 13 dolomite may be interpreted differently (see Chapter 24.1, Kastner and Siever, and 24.2, Gervirtz). It is important to note, however, that in the terminal series of the evaporites, oozes are less and less dolomitized towards the top. This would suggest that the conditions necessary for dolomitization cease at the same time as the evaporitic conditions.

These observations lead us to believe that the dolomites encountered are shallow-water penecontemporaneous dolomites. The frequent association with restricted faunas, together with the presence of gypsum in the middle of the terminal layers, (Sites 124, 132 and 134D) support this point of view.

If the evaporites were deposited under a very thin layer of water, it means that the basin was desiccated. Under these conditions, continental inflow of water could occur. The isotopic analysis of the $\mathrm{O}^{18}$ and $\mathrm{C}^{13}$ content has confirmed this hypothesis and revealed that the greater part of the dolomite was formed under the influence of meteoric waters (see Fontes et al., Chapter 29.1, and Lloyd et al., Chapter 29.1). Isotopic analyses of the sulfur (S34) content have shown a marine origin for the sulfates. All these analyses give clear indication of an alteration of marine and continental conditions at the bottom of the basins during the Messinian.

It is well known that hypersaline environments, such as the sabkhas, do not support life other than algal mats (Shinn et al., 1965; Laporte, 1967; Friedmann, 1969; Braun et al., 1969). All evaporitic series in the Leg 13 cores are characterized by a scarcity, or a total absence, of fossils, as well as, occasionally, by the presence of algal stromatolites.

When a marine basin is isolated and becomes desiccated, the deposits are configured in a "bulls-eye" pattern, with halite in the center, followed by aureoles of anhydrite and gypsum. In view of the few sites and the structural complexity of the basins, it is difficult to say whether Messinian formations exhibit a "bulls-eye" pattern or not. The three drillings, however, might indicate it, with the halite at Site 134 , the deep basin, the anhydrite at Site 124, at the base of the continental rise, and the gypsum at Site 132 , inside a still more marginal basin, some 1000 meters above the level of the central abyssal plain.

Lastly, considerations of the basinal structure, in conjunction with tectonics, add to the data. The presence of continental deposits in the deep Sardinian margin (Site 133), possibly a lateral equivalent of the evaporites of Site 134 , suggests that a desiccated basin probably existed. This 
is not an isolated example. In fact, quite a number of lateral transitions from evaporites to continental formations, or pinching out of evaporites that were followed by a hiatus, have been recognized around the circum-Mediterranean margin (Burrollet et al., 1972).

All these consistent data lead us to favor the deposition of Messinian evaporites in a shallow environment.

\section{The Problem of a Shallow- or Deep-Basin \\ Evaporitic Model}

The assumption that Messinian evaporites have been deposited under a very thin layer of water in no way allows one to judge the depth below sea level of the basin where deposition occurred. This basin could have been similar to the one we know now, that is to say about 2500 meters below sea level in its western part, or shallow, with the bottom generally lying between 100 and 500 meters below sea level.

The geological data supporting either concept of basin type are rather subtle. A number of shipboard scientists favor a deep basin. Their arguments are stated by Hsü et al., in Chapter 43. We shall present here the reasons, as we see them, for a shallow basin with a depth of only some hundred meters.

There are two weighty arguments in favor of a shallow basin, that is, tectonic data and the problem of inter-basin communication. On the other hand, there is an unfavorable one; the deep character of the faunas of the lower Pliocene.

In the western Alps, after the Aquitanian-Burdigalian emplacement of nappes (Durand Delga, 1969), a period of relative quiescence prevailed until the end of the Miocene. There are some minor deformations or discontinuities in the sedimentary series (see Decima and Wezel, Chapter 44.1), but nothing to compare to the great Alpine phases. On the other hand, the Pliocene is a period of very important vertical movements that begin in the Pliocene and continue throughout the Quaternary throughout the entire Mediterranean domain. Such phases are characterized by their irregularity, and their climaxes are separated by periods of quiescence (Bourcart, 1962; Glangeaud, 1962; Pannekoek, 1969). These movements would have raised parts of the Messinian, Pliocene, and even Quaternary, formations along the margins, and then flattened down the central zones of the basins, thus sinking the remainder of the same formations. In some areas, these movements are extremely pronounced. In Tunisia, Burollet (1971) describes a succession of vertical movements that reached an amplitude of 3000 meters.

The geological record reveals, therefore, that numerous shreds of marine Messinian have been carried to an altitude of several hundred meters, not only on the margins of the basins, but several tens of kilometers away from the coast in the interior of the continents as well. The best known of these are the shreds of the Appenines and of Sicily (Ogniben, 1957, Selli, 1960; Decima and Wezel this volume Chapter 44.1). They are followed by other shreds in North Africa (Perrodon, 1957; Glacon and Guiraud, 1970) and in Spain, where thick salt series have been observed (Rios 1968). In the eastern basin, the most spectacular examples come from Cyprus and Turkey, where drilling has penetrated several hundred meters of salt, etc. (Freudenthal, 1969).
However, in opposition to the previous mechanism, seismic profiling reveals the very core of evaporitic formations at the bottom of the basins, under several thousand meters of water and more recent sediments. These basins are characterized by a development of salt diapirs, and can be located in the west as well as in the east inside the deep zones that have an oceanic floor (see above, and Ryan et al., 1971; Wong et al., 1971). Of peculiar interest is the connection which exists between the core of the formation and the peripheral shreds. When one moves away from the central zones of the basins, the evaporitic formations pinch out, while the diapirs disappear altogether. This lateral facies, without diapirs, most probably consists of deposits that are similar to those we have drilled in the Valencia Gulf (Site 122), that is to say, in marls with gypsum.

Seismic reflection establishes that these lateral formations creep along the continental slopes, either following a gentle incline or a series of broken-down tiers (Ryan et al., 1971, Figure 30), as in the Tyrrhenian Sea. Under some of these declivities, the lateral transition from the evaporites to the continental formations has been recognized. This can be seen on the deep margins of Sardinia at our Site 133 (see Chapter 14) and inside the Gulf of Lyon (Mouffrett, personal communication). Under other margins, evaporites pinch out and a hiatus of several millions of years separates the Miocene from the Pliocene or the Quaternary, as has been seen in the Mistral drilling (Burollet et al., 1972), in the Syrte Gulf, at Site 121, and in the Alboran Sea (see Chapter 3).

This strong Plio-Quaternary vertical tectonic movement is not consistent with the assumption of a continuous and regular subsidence of the Mediterranean basins; a foundering that would have begun at the time of the initial oceanization and ended very recently. It is very likely that horizontal stresses have prevented the sinking of the Mediterranean basins before the end of the Messinian.

The ensuing distribution of these tectonic shreds, coincident with the collapse at the center of the basins and accompanied by raising of the margins, must have been post-Messinian in age. The hypothesis of an evaporite deposit that could simultaneously be deposited under a thin layer of water at the bottom of a basin, 2000 meters under the general level of the seas, as well as at the basin margins at nearly the same level, cannot therefore be realistic.

It is to be noted that the shallow-basin model most satisfactorily explains the formation of peri-Mediterranean nappes, such as the ones that have been described in North Africa, Sicily, or Calabria. Indeed, when subduction processes take place, it is only upon occurrence of a slight topographic change of level between lithosperic plates that the sediments that have accumulated upon the plunging slab will work loose and slide in nappes onto the edge of the other plate. If later on, vertical movements affect these plates, it may lead to a disposition similar to that of the present Algerian margin. Under this assumption, the bottom of the western Mediterranean Sea could have collapsed from the Pliocene onwards, some time after the Aquitanian-Burdigalian nappe formation. While the center of the western basin was sinking, the borders of the African block would have reached a new height by compensation 
and, at the same time, raised the nappes, thus facilitating their gravity sliding.

When an important change of level happens to exist at the time of the subduction, the sediments of the sinking plate, lighter than the lithosphere, meet the border of the encasing plate and constitute a fold. This can now be seen in the south of the Hellenic Arch, where the sediments, compressed in a broad anticlime, make up the deep Mediterranean Ridge.

This model could be widened to include all of the orogeneses on the borders of continental blocks.

A principal problem is that of communication between the basins. Towards the end of the Tortonian, the Mediterranean Sea was nearly totally isolated (Gignoux, 1950; Zenkovich, 1966; and Chapter 45). Only one communication remained with the Atlantic, that was through the South-Riff Straits. Yet, the evaporitic formations are known, not only inside the western basin, but also in the eastern part of the Mediterranean Sea and isolated, in the south, from the Indian Ocean (Heybroek, 1965). In the course of the Messinian, therefore, marine water from the Atlantic seems to have fed the eastern basin and the Red Sea as well as the western basin. Moreover, this feeding appears to have proceeded, even if only in an intermittent way, during the entire Messinian episode. Indeed, had the isolation of the Mediterranean been complete, the mere evaporation of the sea could only have led to the deposit of a few tens of meters of salts, while seismic evidence show that there are evaporitic formations 500 to 2000 meters thick. This feeding can only be possible if the thresholds that divide the three basins, that is, Sicilian Straits, Sicily, and Italy on the one hand and the Isthmus of Suez on the other, do not constitute very important topographical barriers. This condition is difficult to envision with the hypothesis of a western basin 2500 meters deep, periodically filling to the brim with marine water.

The only really important argument against a shallow basin is that some authors confer a deep character to the benthic microfaunas of the hemipelagic marl oozes, such as the Trubi, which have covered the evaporitic series at the time of the great Pliocene transgression. It must be noted, however, that it is difficult to accurately determine the depth of deposition of an ooze, and also, that various authors place a broad interpretation on the word "deep". G. Bizon estimates that in the Ionian Islands the water layer where the benthonic microfaunas of the lower Pliocene marl oozes lived must have ranged between 200 and 400 meters (Bizon, 1966; 1967, and personal communication). In a similar way, Decima and Wezel (Chapter 44.1) believe that the marine oozes interbedded in the terminal evaporitic series were deposited in from 200 to 500 meters of water. For the question under debate, this must clearly be considered as a shallow basin. Along the same lines, it should be emphasized that Benson et al., 1971 (Benson, 1971) has found some species of ostracods that usually live in cold water $\left(6^{\circ} \mathrm{C}\right) 1000$ meters deep Pliocene oozes, on top of the evaporites. This discovery led him to assume the existence of a 1000 meter deep threshold that would have connected the Mediterranean with the Atlantic during the Pliocene. The geological and tectonic context of the Gibraltar region does not, however, allow us to consider the existence of a sill of that depth in the Pliocene. Far more probably, we are seeing one of the much rarer cases (about $5 \%$ ) to which Benson draws attention, where the ostracods live in warmer and shallower waters $(500 \mathrm{~m})$.

Apart from arguments of tectonic or facies depth, there is a third body of data linked with the notion of the base level. It remains difficult to interpret them, however, for they may usually agree with the shallow basin model as well as the deep basin one. This is why Hsü et al. (Chapter 43, this volume) could make use of them in their defense of a deep basin model. The mechanisms in question need a vertical drop of only a few hundred meters to have occurred. These particulars correspond to a shallow basin, and it does not follow that one should apply them to the exclusive defense of a deep basin. Accordingly, we will show why their shallow character must be considered.

To begin with, we are concerned with submarine canyons. It is well known that the Mediterranean possesses a truly beautiful system of canyons which differ from other sea canyons in their steeper incline, better cut profile, and younger appearance (Shepard and Dill, 1965). In 1921, De Marchi had already interpreted them as the trace of a subaerial fluviatile system. Later on, Bourcart (1959), having noted their very steep slope, which is much steeper than that of the alpine torrents, believed that here was the evidence of a Plio-Quaternary flexure, subsequent to the time of their excavation. The fact that a single canyon, the canyon of Le Lavandou, which, instead of being perpendicular to the coast, runs parallel to it, presents a slope that can be compared to the streams we now know, would corroborate Bourcart's hypothesis. Very likely, the middle Miocene system was recut during the Messinian subaerial draining and this is what has given such a youthful aspect to the canyons. This erosion, as well as that of the present alpine torrents, needs but several hundred meters to take place.

In the same way, the distribution of terrigenous coarse sands in the Messinian deposits pleads in favor of a moderately deep basin. The central part of the basin is indeed free of coarse particles, and it is only towards the margins, as seen in Italy, that turbidites may be observed inside the evaporitic formations (Giannini and Tongiorgi, 1959). It is well known that turbidity currents require slopes that are both steep and long in order to develop the energy they need for covering the large distances to central zones of the basins (Heezen, 1963). Such is indeed the case today, since the deep zones of the Mediterranean are filled with turbidites (Menard et al., 1965). The restriction of the coarse sands to the margins suggests, therefore, the existence of a shallow basin.

Similar reasoning leads us to conclude that the formation of the Yugoslav karst, during the Messinian, between the Sarmation sea-lakes of southeastern Europe and the salt desert of the Mediterranean, does not require a thousand meter change of sea level. The setting up of a karstic system would require at most some dozens of meters and a shallow basin could well answer this condition.

More generally, every single problem of base level, whether concerning the erosion of the canyons, the formation of karsts or the making of the Nile or Rhone 
Miocene Valleys (see Chapter 44.4), may be explained when one assumes the existence of a shallow basin that was subsequently subjected to considerable subsidence in the Plio-Quaternary.

\section{CONCLUSION: THE ORIGIN OF THE MESSINIAN MEDITERRANEAN EVAPORITES; A SHALLOW- WATER, SHALLOW-BASIN MODEL}

In conclusion, it is necessary to propose a model which will account for the observed data.

The Messinian evaporitic series of the Mediterranean Sea consists of interstratified massive salts (halite, anhydrite, and gypsum) and layers originally thought to be of marine marl oozes, which are presently dolomitized. These alternations are overlain by marl oozes with gypsum, more or less dolomitized. The evaporitic formation terminates abruptly and is unconformably overlain by Pliocene pelagic oozes.

One should add that our drillings have penetrated only the uppermost 50 to 70 meters of the evaporitic series, while their total thickness, recognized seismically, may reach from 500 to 2000 meters. This can mean that our model coincides fundamentally with the terminal part of the evaporitic episode.

To settle under an extremely thin layer of water, evaporites require a desiccated basin, that is to say, a basin isolated from the world ocean; such was the case for the Mediterranean Sea during the Messinian. If the salts, whose isotopes have indicated a marine origin, have to be deposited in several layers corresponding to far more than a single epoch of evaporation of the basin, any model proposed for their origin requires a source of sea water. In order to do this, it is of course necessary to have its bottom lower than that of the world ocean level. The communication should also be intermittent, so that periods of marine conditions may alternate with stages of desiccation and salt deposition. During the momentary suspension in the supply of salt water, inflows of continental waters may turn the basins into lakes.

Finally, the bottom of the periodically desiccated Mediterranean Sea may be more or less shallow than the level of the other seas. It is tempting to propose its present depth of 2500 to 3000 meters. The numerous geological arguments stated above, the main one of which is the existence of an extremely important post-Messinian vertical tectonic movement in the Mediterranean area, have led us to decide in favor of a depth of around 200 to 500 meters.

Thus, in the Serravallian, the Mediterranean Sea could have been made up of a series of shallow basins between which circulation would have been difficult. In the Messinian, communication with the world ocean became more and more difficult until it terminated. The various basins became desiccated; the residual waters were concentrated in the deepest zones, such as the oceanic bottom trough of the western basin where halite began to settle. A reopening in the Gibraltar area again brought water to all the basins up to the Red Sea, and a marine regime was restored for a short period. It was soon followed by a new desiccation. This condition of intermittent flooding lasted during the whole of the Messinian; the deep trough was then filled with a thick evaporite series, while the slopes of the basins, higher up and covered by continental alluvia, might receive thin peripheral deposits. Toward the end of this period, the oceanic bottom trough of the western basin was practically filled to the brim. At the very end, this state was altered, as marl oozes with gypsum constituted the terminal layers of the evaporitic series, thus indicating less severe evaporitic conditions.

Within the Pliocene, open communication with the Atlantic was fully restored, and was never again to be interrupted. This communication also established marine conditions in the Red Sea through the Suez Portal. The Atlantic waters flooded a Mediterranean Sea that was some hundred meters deep, and pelagic oozes of the Trubi type started to accumulate. It was about that time, too, that important vertical tectonic movements began to take place. They led to the collapsing of the center of the basins and gave the Mediterranean Sea more or less its present physiography.

\section{REFERENCES}

Alinat, J. and Cousteau, J., 1962. Accidents de terrain en mer de Ligurie. In Océanographie géologique et géophysique de la Mediterranee occidentale, Paris, Centre national de la recherche scientifique. 121.

Benson, R. H. and Sylvester-Bradley, P. C., 1971. Deep-sea ostracods and the transformation of ocean to sea in the Tethys. In Oertli, H. J. (Ed.), Paleoecologic OstracodesPan, 1970. Bull., Centre Rec. Pan-SNPA, 5 suppl. 63.

Benson, R. H. 1971. Ostracods as indicators of threshold depth in the Mediterranean during Pliocene. Abstract, 8th Int. Sedim. Congr., Heidelberg.

Bizon, G., 1966. Etude geologique de l'Epire et de la Grece Nord-Orientale Technip ed. Paris.

1967. Contribution a la connaissance des foraminiféres planctoniques d'Epire et des iles Ioniennes. Technip ed. Paris.

Bourcart, J., 1959a. Les sédiments précontinentaux profonds dans le Golfe de Genes. Deep Sea Res., 5, 215.

,1959b. Morphologie du précontinent des Pyrenees a la Sardaigne, In La Topographie et la Géologie des Projondeurs Océaniques, Colloques Internationaux C.N.R.S., Nice-Villefranche, Mai. 1958. 33. , 1962. La Méditerrannée et la révolution du Pliocène. Livre à la mémoire du Professeur P. Fallot. Societe Geologique de France. 1, 103.

Bourcart, J. et al., 1958. Les sediments profonds au large de la cote nicoise. C. R. Ac. Sc. Paris. 147, 116.

Braun, Moshe and Friedman, G. M., 1969. Carbonate lithofacies and environments of the Tribes Hill Formation (Lower Ordovician) of the Mohawk Valley, New York. J. Sediment. Petrol. 39, 113.

Burollet, P.F. 1971. Remarques Geodynamiques sur le Nord-Est de la Tunisie. C. R. Somm. Soc. Geol. France. 8 (seance du 22 Novembre 1971).

Burollet, P. F. and Dufaure, Ph., 1972. The Neogene series drilled by the sell MISTRAL no. 1 in the Gulf of Lion. In The Mediterranean Sea. D. J. Stanely (Ed.), Dowden, Hutchinson and Ross, Inc.

Cogne, J., Geze, B., Goguel, J., Grolier, J., Letourneur, J., Pellet, J., Rothe, J. and Sitter, C., 1966. Les rifts et les failles de decrochement en France. Rev. Geogr. Phys. Geol. Dyn. (2) 8, 123.

Degens, E. T. and Epstein, S., 1964. Oxygen and carbon isotope ratios in coexisting calcites and dolomites from recent and ancient sediments. Geochim. Cosmochim. Acta. 28, 23. 
Durand, Delga M., 1969. Miss au point sur la structure du Nord-Est de la Berberie. Publ. Serv. Geol. Algerie. (N1 le Serie). Publ. 39, 89.

Ewing, W. M., Worzel, J. L. et al., 1969. Initial Reports of the Deep Sea Drilling Project, Volume I. Washington (U. S. Government Printing Office).

Falquist, D. A. and Hersey, J. B., 1969. Seismic refraction measurements in the western Mediterranean sea. Bull. Inst. Oceanogr. Monaco. 67, 1 .

Freidman, G. M. and Sanders, J. E., 1967. Origin and occurrence of dolostones, pp. 267-348 In Chilingar, G. V., Bissell, H. J., and Fairbridge, R. W. (Eds.), 1967. Developments in Sedimentology, 9a, Carbonate rocks. Elsevier, Amsterdam, 471 p.

Friedman, G. M., 1969. Recognizing tidal environments in carbonate rocks with particular reference to those of the lower Paleozoics in the Northern Appalachians. Geological Society of America, Northeastern Section Fourth Annual Meeting, Abstracts with Programs for 1969. Part I, 10.

Garrels, R. M. and Christ, C. L., 1964. Solutions, Minerals, and Equilibria. Harper and Row, New York.

Giannini, E. and Torgiorgi, M., 1959. Stratigrafia neogenica toscana. Boll. Soc. Geol. Italiana. 78 (2).

Gignoux, Mr. 1950. Geologic Stratigraphique. Masson. Paris.

Glacon, G. and Guiraud, R., 1970. La série Mio-Pliocene du Hodna et des régions voisines (Algérie du Nord). Compte Rendus, Acad. Sc. Paris. 271, 945.

Glangeaud, L., 1962. Paleogeographie de la Mediterranee et de ses bordures. Le role des phases ponto-plio-quaternaires. Oceanogr. geologique et geogr. Medit. occ. Colloq. Centre Nat. Rech. Sc., 125.

Glangeaud, L., Alinat, J., Polveche, J., Guillaume, A. and Leenhardt, D., 1966. Grandes structures de la mer Ligure, leur evolution et leurs relations avec les chaines continentales, Bull. Soc. Geol. France. 7, 921.

Goldsmith, J. R. and Graf, D. L., 1958. Structural and compositional variations in some natural dolomites. $J$. Geol. 66, 678 .

Hardie, J. L. and Eugster, H. P., 1971. The depositional environment of marine evaporites: a case for shallow, clastic accumulation. Sedimentology. 16, 187.

Heezen, B. C., 1963. Turbidity currents. The Sea. 3, 742. John Wiley and Sons, New York.

Heezen, B. C., Gry, C., Segre, A. G. and Zarudski, E. F. K., 1971. Evidence of foundered continental crust beneath the central Tyrrhenian Sea. Nature. 229 (583), 327.

Hersey, J. B., 1965. Sedimentary basins of the Mediterranean Sea. In Submarine Geology and Geophysics. W. F. Whittard and R. Bradshaw (eds.)

Heybroek, F., 1965. The Red Sea Miocene Evaporite Basin. In Salt Basins around Africa, 17. The Institute of Petroleum, London, Elsevier.

Lambo, W. A., 1964. Geology of the Silver Plains gypsum deposit. Master's Thesis, University of Manitoba, $91 \mathrm{p}$.

Laporte, L.F., 1967. Carbonate deposition near mean sea-level and resultant facies mosaic: Manlius Formation (Lower Devonian) of New York State: Bull Am. Assoc. Petrol. Geologists. 51, 73.

Menard, H. W., Smith, S. M. and Pratt, R. M., 1965. The Rhone deep-sea fan. In Submarine Geology and Geophysics, W. F. Whittard and R. Bradshaw (Eds.), Proc. 17th Symposium Colston Res. Soc. Butterworths, London. 271.

Mauffret, A. 1969. Les domes et les structures "anticlinales" de la Mediterranee occidentale au nord-est des
Baleares, Revue de l'Institut Francais du Petrole et Annales des Combustibles Liquids. 24 (7-8), 953.

Murray, R. C., 1964. Origin and diagenesis of gypsum and anhydrite. J. Sediment Petrol. 34, 512.

Ogniben, L., 1957. Petrografia della serie Solfigera Siciliana e considerazioni geologiche relative. Mem. des Carta Geol. Italia. 33. 1.

Perrodon, A., 1957. Etude geologiques des bassins neogenes sublittoraux de l'Algerie occidentale. Publ. Serv. Carte Geol. alg. N.S. bull. 12.

Peterson, M. N. A., Edgar, N. T. et al., 1970. Initial Reports of the Deep Sea Drilling Project, Volume II. Washington (U. S. Government Printing Office).

Rios, J. M., 1968. Saline Deposits of Spain. G. S. A., Inc., Special Paper. 88, 59.

Rooney, L. F. and French, R. R., 1968. Allogenic quartz and the origin of penemosaic texture in evaporites of the Detroit River Formation (Middle Devonian) in Northern Indiana. J. Sediment. Petrol. 38, 755.

Ryan, W. B. F., Stanley, D. J., Hersey, J. B., Fahlquist, D. A. and Allan, T. D., 1971. The Tectonics and Geology of the Mediterannean Sea. In The Sea. 4 (ch. 12), 387 .

Schmaltz, P. F., 1969. Deep-water evaporitic deposition: A genetic model. Bull. Am. Assoc. Petrol. Geologists. 53 (4), 798.

Sclater, J. G., 1972. Heat Flow and Elevation of the Western Pacific. J. Geophys. Res. (In press).

Selli, R., 1960. Il Messiniano Mayer-Eymar 1967. Proposta di un neostratotipo. Giorn. Geol. 28 (fasc. 2), 1.

Shearman, D. J., 1966. Origin of marine evaporites by diagenesis. Inst. Mining Metallurgy Trans. 75, 208.

Shearman, D. J. and Fuller, J. G., 1969. Anhydrite diagenesis, calcitization, and organic laminites, Winnipegosis Formation, Middle Devonian, Saskatchewan. Bull Can. Petrol. Geol. 17, 496.

Shepard, F. P. and Dill, R. F., 1966. Submarine Canyons and other Sea Valleys. Rand McNally and Co., Chicago.

Shinn, E. A., 1968. Selective dolomitization of Recent sedimentary structures. J. Sediment. Petrol. 38, 612.

Shinn, E. A., Ginsburg, R. N. and Lloyd, R. M., 1965. Recent supratidal dolomite from Andros Island, Bahamas, 112-123. In Pray, L. C., and Murray, R. C., Dolomitization and limestone diagenesis, a symposium. Soc. Econ. Paleontologists and Mineralogists, Spec. Pub. 13,180 .

Strakov, N. M., 1969. Principles of Lithogenesis. 2, Oliver and Boyd, Edinburg.

Textoris, D. A. and Carozzi, A. V., 1966. Petrography of a Cayugan (Silurian) stromatolite mound and associated facies, Ohio. Bull. Am. Assoc. Petrol. Geologists. 50, 1375 .

Watson, J. A. and Johnson, G. L., 1968. Mediterranean diapiric structures. Bull. Am. Assoc. Petrol. Geologists. 52, 2247.

Wong, H. K., Zarudzki, E. F. K., Knott, S. T. and Hayes, E. E., 1970. Newly discovered group of diapiric structures in the western Mediterranean. Bull Am. Assoc. Petrol. Geologists. 54, 2200.

Wong, H. K., Zarudzki, Phillips, J. D. and Giermann, G. K. F., 1971. Some Geophysical Profiles in the Eastern Mediterranean. Bull. Geol. Soc. Am. 82, 91.

Zenkovich, V.P., 1966. Black Sea. In Encyclopedia of Oceanography, R. W. Fainbridge, Ed., Reinhold Pub. Co., New York. 